\title{
Son Değişiklikler Çerçevesinde Patent Hakkının Haczi*
}

\author{
Fikret Sami TIYYEK \\ Ar. Gör., Pamukkale Üniversitesi, İktisadi ve İdari Bilimler Fakültesi, Ticaret Hukuku Anabilim Dalı, \\ ftiyek@pau.edu.tr, (Sorumlu Yazar / Corresponding Author) \\ Önder TOPAL \\ Dr. Öğr. Üyesi, Trabzon Üniversitesi, Hukuk Fakültesi, Medeni Usul ve İcra-İflas Hukuku Anabilim Dalı, \\ ondertopal61@gmail.com
}

\begin{tabular}{ll}
\hline Makale Bilgileri & Öz \\
\hline Makale Geçmişi & Sınai mülkiyet hukukunu düzenleyen dağınık hükümler, 6769 sayılı Sınai Mülkiyet Kanunu ile bir \\
Geliş: 28.04.2021 & yerde toplanmışır. Bu Kanun, sınai mülkiyet hakkı kapsamında yer alan patent hakkına ilişkin bazı \\
Kabul: 22.06.2021 & yenilikler getirmiştir. Bu yeniliklerden birisi de patent hakkının haciz işlemine konu olmasıla ilgilidir. \\
Yayın: 23.06.2021 & Patent hakkının, sahibinin borcundan dolayı haczedilebileceği, Kanun'da açıça ifade edilmiştir. \\
& Ancak, haczin konusu ve haczin icra edilmesi noktasında herhangi bir belirleme söz konusu değildir. \\
& Çalışmamızda öncelikli olarak patente ilişkin temel kavram ve haklara genel olarak yer vererek, patent \\
Anahtar Kelimeler: & hakkının haczinin konusunu ve icrasını daha anlaşılır bir şekilde ortaya koymaya çalışacağız. Bu \\
Patent, Buluş, Patent & itibarla, "patent hakkı" olarak ifade edilen ve haczin de konusunu oluşturan kavramın, kapsamı \\
İsteme Hakk1, Patentten & belirlenecektir. Öte yandan, haczin gerçekleştirilmesine ilişkin ne Sınai Mülkiyet Kanunu'nda ne de \\
Doğan Hak, Haciz & 2004 sayıllı İcra ve İflas Kanunu'nda açı hüküm bulunmaktadır. Fakat yine de haciz İcra ve İflas \\
& Kanunu hükümler çerçevesinde icra edilecektir. Bu bakımdan haczin gerçekleştirilmesinde Kanun'un \\
& hangi hükümlerinin işlerlik kazanacağına, hangilerinin ise uygulanamayacağına yönelik bir belirleme \\
& yapıllacaktır. Bu sirada da yeni bir kanuni düzenleme yapılmasının gerek olup olmadığına da \\
& çalışmamızda yer verilecektir.
\end{tabular}

\section{Attachment Of Patent Rights Under The Recent Changes}

\begin{tabular}{ll}
\hline Article Info & Abstract \\
\hline $\begin{array}{l}\text { Article History } \\
\text { Received: 28.04.2021 } \\
\text { Accepted: 22.06.2021 } \\
\text { Published: 23.06.2021 }\end{array}$ & $\begin{array}{l}\text { The dispersed provisions regulating the industrial property law have been gathered in one place under } \\
\text { the Industrial Property Law No. 6769. This Law has introduced several novelties regarding the patent } \\
\text { right, which is within the scope of industrial property right. One of these novelties is related to the } \\
\text { patent right being subject to the attachment proceedings. It is clearly stated in the Law that the patent } \\
\text { right can be attached due to the owner's debts. However, the subject and the execution of the } \\
\text { attachment have not been determined. In our study, we will try to reveal the subject and execution of } \\
\text { the attachment of the patent right in a more understandable way, primarily by including the basic } \\
\text { concepts and rights related to the patent in general. In this respect, the scope of the concept, which is } \\
\text { Keywords: }\end{array}$ \\
$\begin{array}{l}\text { Patent, Invention, Right } \\
\text { to Request a Patent, } \\
\text { Right Arising from a } \\
\text { Patent, Attachment }\end{array}$ & $\begin{array}{l}\text { hand, neither the Industrial Property Law nor the Enforcement and Bankruptcy Law No. 2004 have } \\
\text { explicit provisions regarding the execution of attachment. However, the attachment will still be } \\
\text { enforced within the framework of the provisions of the Enforcement and Bankruptcy Law. In the } \\
\text { realization of the attachment, a determination will be made as to which provisions of the Law will } \\
\text { become effective and which cannot be applied. Meanwhile, our study will also cover as to whether a } \\
\text { new legal regulation is required. }\end{array}$ \\
\hline
\end{tabular}

Atıf/Citation: Tiyek, F. S., Topal, Ö. (2021). Son Değişiklikler Çerçevesinde Patent Hakkının Haczi, Necmettin Erbakan Üniversitesi Hukuk Fakültesi Dergisi, 4(1), s. 243-275.

Plagiarism: Bu makale intihal programında taranmış ve en az iki hakem incelemesinden geçmiştir. // This article has been scanned via a plagiarism software and reviewed by at least two referees.

\footnotetext{
* Bu makale 10-12 Nisan 2021 tarihinde Uluslararası Necmettin Erbakan Hukuk Kongresi'nde sunulan özet bildirinin genişletilmiş halidir.
} 


\section{GíRiş}

Sınaî mülkiyet haklarına ilişkin olarak 6769 sayılı Sınai Mülkiyet Kanunu (SMK), 10.01.2017 tarih ve 29944 sayılı Resmi Gazete'de yayınlanarak yürürlüğe girmiştir. Sınaî mülkiyet hakkı kavramı markayı, coğrafi işareti, tasarımı, patent ve faydalı modeli kapsamaktadır. Anılan Kanun'un yürürlüğe girmesiyle birlikte marka, coğrafi işaret, tasarım, patent ve faydalı modele ilişkin Kanun Hükmünde Kararname'lerin (KHK) yürürlüğüne son verilmiştir. SMK, anılan sınai mülkiyet haklarına ilişkin KHK'lara paralel düzenlemeleri içermekle beraber, birçok yeni düzenlemeyi bünyesinde barındırmaktadır ${ }^{1}$. Örneğin patent hakkının haczine ilişkin olarak 551 Sayılı Patent Haklarının Korunması Hakkında Kanun Hükmünde Kararname'de (PatKHK) ve 5175 Sayılı Patent Haklarının Korunması Hakkında Kanun Hükmünde Kararnamenin Uygulama Şeklini Gösterir Yönetmelik'te (PatKHKY) herhangi bir düzenleme yer almazken, SMK m. 148/1'de ve Sınaî Mülkiyet Kanunu'nun Uygulanmasına Dair Yönetmelik (SMKY) m. 126'da özel hüküm yer almaktadır. Söz konusu hükümler çerçevesinde sınai mülkiyet haklarının ve özellikle inceleme konumuzu oluşturan patent hakkının, haczi caiz olan malvarlığı unsurları arasında yer aldığ 1 anlaşılmaktadır.

Sınaî mülkiyet haklarının, daha geniş bir ifadeyle gayri maddi mallar üzerindeki mutlak hakkın haczine ilişkin olarak 2004 sayılı İcra ve İflas Kanunu'nda (İIK) herhangi bir özel düzenleme bulunmamaktadır. Her ne kadar sınai mülkiyet haklarının haczedilebileceği, ilgili kanunda düzenlenmiş olsa da hangi usule göre haczin gerçekleştirileceğine ilişkin olarak açık bir hüküm sevk edilmemiştir. Hatta sınai mülkiyet haklarının haczi konusunda İİK'nın hangi hükümlerinin işlerlik kazanacağı konusu da doktrinde tartışılmaktadır. Zira, SMK ve SMKY, sınai mülkiyet haklarının ve bu kapsamda patent hakkının da haczini açıcça düzenlemekte ve fakat haczin nasıl gerçekleşeceği konusunda herhangi bir düzenleme içermemektedir. Haczin gerçekleşmesi hususunda anılan kanunda hüküm olmaması normaldir; zira hacizle ilgili hükmün, İcra ve İflas Kanunu'nda yer alması beklenmektedir. Fakat az önce ifade ettiğimiz üzere gayri maddi mallar üzerindeki mülkiyet hakkının, bu kapsamda sınai mülkiyet haklarının ve dolayısıyla patent hakkının haczine ilişkin olarak İIK'da doğrudan hükümler olmadığından; bu eksikliğin giderilmesi için gerekli kanun değişikliklerinin yapılması büyük önem ifade etmektedir. Anılan hususta, kanun değişikliği yapılana kadar, mevcut düzenlemeler çerçevesinde patent hakkının haczine ilişkin olarak İIK'nın hangi hükümlerinin işlerlik kazanacağı noktasında belirlemeler yapmak gerekir.

Patent hakkının haczine ilişkin olarak değerlendirmelere geçmeden önce, ilk olarak SMK kapsamında patent hakkına yer vermekte fayda vardır. Bir başka ifadeyle patent hakkının haczinin konusunun ne olduğunun tespit edilebilmesi için SMK kapsamında patentin ne anlama geldiğinin açıkça ortaya koyulması gerekmektedir. Bu sebeple çalışmamızda, patent ile ilgili kavramlar, patent ve patent hakkı kavramları, sonrasında ise patent hakkının haczine yer verilecektir. Aşağıda sırasıyla bu konular ele alınıp değerlendirilecektir.

\footnotetext{
SMK'nın sınai mülkiyet hukuku bağlamında getirmiş olduğu yenilikler inceleme konumuzun kapsamı dışındadır.
} 


\section{PATENT KAVRAMI}

\section{A. Patentin Tanımı ve Unsurları}

Dil bilimi bakımından "açık olmak” anlamına gelen patent kavramı, Krallıklar döneminde, altı mühürlenen, üst tarafı mühürlenmeden rulo halinde önemli mevkilere atanan, kendilerine imtiyazlar tanınan ya da bir buluş yapan kişilere verilen, Latince "literae patentes" olarak adlandırılan açık, mühürle kapatılmamış mektuplardan türemiştir²

Türk patent hukukumuzun temel düzenlemelerinden olup yürürlükten kaldırılan PatKHK ve PatKHKY kapsamında "ihtira beratı" kavramının ${ }^{3}$ yerine "patent" ifadesi benimsenmiş, ancak patent kavramının tanımı yapılmamıştır.

Sınaî mülkiyet hukukunun, dağınık ve kanun hükmünde kararnamelerle belirlenmeye çalışılan temel kuralları, nihayet 10.01.2017 tarihinde yürürlüğe giren 6769 sayılı Sınai Mülkiyet $\mathrm{Kanunu}^{4}$ (SMK) ile tek bir çatı altında toplanmışsa da, ne bu Kanun'da ne de SMKY'de ${ }^{5}$ patent kavramının tanımına yer verilmiştir.

Doktrinde patente ilişkin yapılan farklı tanımlar bulunmakla birlikte, tüm unsurlarını kapsayacak şekilde bir tanım yapmak gerekirse; patent, teknolojinin buluş yapmaya müsait her alanında fikri çaba ürünü olarak ortaya çıkan buluşlara yeni olması, buluş basamağı içermesi ve sanayiye uygulanabilir olması şartıyla resmi makamlarca verilen ve bu çerçevede sicile tescille birlikte üçüncü kişilere karşı Sınai Mülkiyet Kanunu kapsamında koruma sağlayan belge olarak tanımlanabilir ${ }^{6} 7$.

Yukarıda yer verdiğimiz tanımdan da anlaşılacağı üzere patentin unsurları, "yenilik", "buluş basamağı" ve "sanayiye uygulanabilirlik" olarak ifade edilebilir (SMK m. 82/1).

2 Tekinalp, Ünal. Fikrî Mülkiyet Hukuku, 5. Baskı, Vedat Kitapçılık, İstanbul, 2012, s.523; Saraç, Tahir (Karahan, Sami/Suluk, Cahit/Saraç, Tahir/Nal, Temel). Fikri Mülkiyet Hukukunun Esaslarl, 3. Bası, Seçkin Yayıncılık, Ankara, 2012, s.199; Suluk, Cahit (Karasu, Rauf/Nal, Temel). Fikri Mülkiyet Hukuku, 4. Baskı, Seçkin Yayıncılık, Ankara 2020, s.231.

3 Benzeri görülmemiş bir şey icat etme, vücuda getirme anlamındaki ihtira beratı kavramı, 13 Mart 1879 tarihinde yürürlüğe giren İhtira Beratı Kanunu ile ilk defa kullanılmış, günümüzde yerini patent kavramına bırakmıştır (Saraç, 2012, s.199).

$4 \quad$ 10.01.2017 tarih ve 29944 sayılı RG.

$5 \quad$ 24.04.2017 tarih ve 30047 sayllı RG.

6 Doktrinde yer verilen diğer tanımlamalar için bkz. Suluk, 2020, s.231; Erdem, Bahadır. Patent Hakkının Korunmasına ve Patent Hakkına İlişkin Sözleşmelere Uygulanacak Hukuk, 2. Bası, Beta Yayıncılık, İstanbul, 2002, s.22; Hirş, E. Eduard. Fikrî ve Sınaî Haklar, Ankara Üniversitesi Hukuk Fakültesi Yayınları, Ankara, 1948, s.78; Kaya, Arslan. "Türk Hukukunda Patentten Doğan Haklar”, İstanbul Üniversitesi Hukuk Fakültesi Dergisi, 1997, C. LV, S. 4, 1997, (s.173-200), s.173; Saraç, 2012, s.200; Tamer, Ahmet. Patent ve Faydalı Model Hakkına Aykırılı̆̆ın Sonuçları, Bilge Yayınevi, Ankara, 2013, s.13; Şehirali, Feyzan H. Patent Hakkının Korunması, Turhan Kitapevi, Ankara, 1998, s.7; Sarı, Onur. Patent Lisans Sözleşmeleri, Seçkin Yayınları, Ankara, 2019, s.2728, https://ws1.turcademy.com/ww/webviewer.php?doc=23027, (Erişim Tarihi: 03.01.2021).

7 Patent kavramı dar ve geniş anlamda patent olmak üzere ikili bir ayrıma tabi tutulabilir (Suluk, 2020, s.231; Saraç, 2012, s.199). Buna göre dar anlamda patent, kanunda belirtilmiş koşulları taşıyan buluşlar için patent hakkını kanıtlaması amacıyla verilen bir belgedir. Geniş anlamda patent ise patent verilmesi ile buluş üzerinde inhisarî kullanım yetkisini sağlayan mutlak hakkı ve bu hakkı ispata yarayan belgeyi ifade eder (Kaya, 1997, s.173; Suluk, 2020, s.231; Saraç, 2012, s.199). 
Tekniğin bilinen durumuna dâhil olmayan buluşun yeni olduğu kabul edilmektedir (SMK m. 83/1). Bu kapsama, başvurudan önce dünyanın herhangi bir yerinde, yazılı ya da sözlü olarak ortaya konulmuş veya kullanım gibi bir şekilde açıklanan, herkesin erişebildiği şeyler girer (SMK m. 83/2). Tekniğin bilinen durumu, başvuru tarihinde ya da sonrasında yayımlanan ve önceki tarihli ulusal patent ve faydalı model başvurularının ilk içeriklerini kapsar (SMK m. 83/3).

Tekniğin bilinen durumunu dikkate alarak ilgili teknik alandaki uzman tarafından aşikar olarak kabul edilmeyen buluşların, buluş basamağını içerdiği kabul edilir ${ }^{8}$ (SMK m. 83/4).

Buluşun sanayiye uygulanabilirliği, herhangi bir sanayi alanında (tarım dâhil) üretilebilir ya da kullanılabilir olup olmamasına göre belirlenir (SMK m. 83/6).

Tüm bu anlatılanlar çerçevesinde tekniğin bilinen durumunu aşan ve sanayiye uygulanabilir olan buluşların, patent verilerek korunabilir nitelikte olduğuna işaret edilmelidir. Buluş olarak değerlendirilemeyecek haller SMK'nın 82. maddesinin ikinci fikrasında ve buluşa patent verilemeyecek haller ise aynı maddenin üçüncü fıkrasında düzenleme altına alınmıştır.

\section{B. Buluş Kavramı ve Unsurları}

Patent belgesi verilmesi için ortada bir buluşun varlığı gerekir ve buluşun tanımlanması, patent kavramının anlaşılabilmesi için elzem dir ${ }^{9}$. Bu itibarla buluş, fikri veya fiziki bir çaba sonucu ortaya çıkmış olan, halihazırdaki durumu ilerletici nitelik taşıyan veya ortaya çıkan sorunu teknik alan kapsamında, uygulanabilir bir öğretiyle çözen kurallar getiren teknik çözümleme, proje ve fikir ürünü olarak ifade edilebilirr ${ }^{10}$. Bu kapsamda buluşun unsurları; teknik alan, uygulanabilir bir öğreti ve çözümdür ${ }^{11}$.

Öncelikle bir buluştan söz edilebilmesi için teknik bir alanın mevcudiyeti şarttır. Teknik alandan kasıt doğadır ve teknik alanı bir doğa kanununun keşfi, bilimsel bir sürecin izlenmesi, toplanan materyallerin denenmesi ve incelenmesi, iktisadi hesaplar ve özel deneyler yapmak gibi

8 SMK m. 83/3 bağlamında tekniğin bilinen durumu kapsamında değerlendirilen başvuruların ve belgelerin içerikleri, buluş basamağının incelenmesinde dikkate alınmazlar (SMK m. 83/5).

9 Saraç, 2012, s.205; Şehirali, s.6; Tamer, s.14.

10 İhtira ve buluş kavramını birbirinden ayırmayan görüş için bkz. Hirş, s.77. Tekinalp ise buluşu, bir beşeri gereksinim olarak ortaya çıkan soruna teknik alana giren, uygulanabilir bir öğreti ile çözüm getiren fikri bir ürün olarak tanımlamıştır (Tekinalp, 2012, s.530). Bir tanıma göre buluş, bir problemin çözümüne ilişkin teknik kuraldır (Saraç, 2012, s.204). Başka bir tanıma göre buluş, insan zekasının ürünü olan, özel, teknik bir problemin çözümünü sağlayan, teknik bir kural getiren yenilik unsuru taşıyan, ürünlere ya da usullere ilişkin olan bir fikirdir (Şehirali, s.7). Bir diğer tanımlamaya göre ise teknik buluş, doğal kuvvetlerin hâkimiyet altına alınması bakımından bir ilerleme kaydetmeyi ifade eder (Ayiter, Nuşin. İhtira Hukuku, Ankara Üniversitesi Hukuk Fakültesi Yayınları, Ankara, 1968, s.30). Kısa ve soyut bir tanıma göre ise buluş teknik bir eylemle ilgili kuraldır (Ortan, Ali Necip. İşçi Buluşları Hukuku, Dokuz Eylül Üniversitesi Yayınları, İzmir, 1987, s.46). Bir diğer yazar buluşu, teknik bir soruna getirilen yeni çözüm şeklinde tanımlamıştır (Erdem, s.21). Buluş, teknik bir problemi çözen ve yenilik özelliği taşıyan insan fikridir (Suluk, 2020, s.231). En kısa şekilde buluş, bir problemin çözümüne ilişkin teknik kural olarak tanımlanmaktadır (Güneş, İlhami. Sınai Mülkiyet Kanunu Işı̆̆ında Uygulamalı Patent ve Faydalı Model hukuku, 3. Bask1, Seçkin Yayıncılık, Ankara, 2020, s.142).

11 Hirsch, E. Eduard. Hukuki Bakımdan Fikrî Say, Cilt I, İstanbul Üniversitesi Hukuk Fakültesi Yayınları, İstanbul, 1942, s.114-115; Tekinalp, 2012 , s.530; Engelbert, Marina, Pfändung ausgewählter Immaterial-güterrechte, FHVR, Heft 64, 2007, https://www.hwr-berlin.de/fileadmin/portal/Dokumente/FachbereicheInstitute/FB4/Forschung/FB-4-Heft-2007-64.pdf, Erişim Tarihi: 08.03.2021, s.19. 
çok geniş bir yelpaze oluşturabilir. Önemli olan husus, doğanın hakimiyet altına alınması ve bir sonuca ulaşılmasıdır ${ }^{12}$.

Buluş, sadece fikri bir ürün olarak soyut/düşünce aşamasında kalmamalıdır ${ }^{13}$. Gösterilen faaliyet sonrasında hayata geçirilme vasfina sahip, uygulanabilir bir ögretinin somut olarak ifade edilebilmesi ve teknik bir meselenin çözüme kavuşması durumu, tekrar edilebilir olmalıdır ${ }^{14}$.

Son olarak, buluşun, üzerinde çalışılan soruna çözüm getirmiş olması aranır ${ }^{15}$. Buluşla getirilen çözümün o alanda farklı görünüm biçimleri olsa bile somut olarak ortaya konulmasına bakılır. Bu yapılırken, yeni bulunan bir yöntem, bir cisim ya da yeni bir maddenin keşfinden bahsedilebilir ${ }^{16}$.

\section{Patent Hakkı ve Patent Hakkının Hukuki Niteliği}

Burada tanımını yapmış olduğumuz patent kavramı, doktrinde geniş anlamda patent olarak kabul edilen kavramdır ${ }^{17}$. Bu geniş tanımlama çerçevesinde patent ifadesinden ziyade uygulama ve literatürde "patent hakkı" terimi kullanılmakta ve bununla patent sahibine ait tüm yetkileri kapsayan genel bir hak kategorisi anlatılmak istenmektedirr ${ }^{18}$. Aşağıda da ifade edileceği üzere, buluşla ilgili haklar ve patent başvurusuyla patent alındıktan sonraki süreçte ortaya çıkan haklar, bu çalışmada irdelenecektir ${ }^{19}$.

Patent hakk1, gayrimaddi mallar üzerindeki mutlak hakkı ifade eden sınai bir haktır ${ }^{20}$. Gayrimaddi mallar, Türk Medeni Kanunu (TMK) kapsamındaki menkul mallar dışında, insan zekasının yaratıcı ürünü olup, üstünde cisimlendiği maddi mallardan ayrılan ve ayrı bir hukuki varlığa ve ekonomik değere sahip haklardır ${ }^{21}$. Patent hakkı da gayrimaddi mal olması sebebiyle üzerinde bulunduğu ürün veya usulden farklı olarak değerlendirilebilir. Bu itibarla patent hakk1, sahibine, maddi ve manevi menfaatler sağlayan, patent verilmiş buluş üzerinde sınırsız bir şekilde kullanım hakkı sağlayan mutlak haktır ${ }^{22}$. Patent hakkı, ayrı ve bağımsız bir malvarlığı unsuru oluşturur ve miras yoluyla intikal edebileceği gibi, lisansa konu edilebilir, rehin verilip, teminat olarak gösterilebilir, haczedilebilir veya diğer hukuki işlemlerde yer alabilir (SMK m. 148/1, SMKY m. 125 vd.).

12 Hirş, s.80; Saraç, 2012, s.204; Tekinalp, 2012, s.530; Sarı, s.36.

13 Tekinalp, 2012, s.533.

14 Ayiter, s.36-37; Hirsch, C. I, s.118; Sarı, 36.

15 Ayiter, s.31; Saraç, 2012, s.205.

16 Tekinalp, 2012, s.534.

17 Bu yönde bkz. Saraç, 2012, s.199-200; Kaya, 1997, s.173.

18 Saraç, 2012, s.200.

19 Saraç, 2012, s.200.

20 Fikri mülkiyet hakları, maddi olmayan mallar üzerindeki mutlak hakların başında gelir ve hukuken korunurlar (İmre, Zahit. Medeni Hukuka Giriş, Yenilenmiş ve Genişletilmiş İkinci Bası, İstanbul, 1976, s.237).

21 Erel, Şafak. Türk Fikir ve Sanat Hukuku, 3. Bası, Yetkin Yayınları, Ankara, 2009, s.26.

22 Erdem, s.47. Bir başka tanıma göre patent hakkı "devlet tarafindan sağlanan ve sahibine, konusunu teşkil eden buluşun münhasır yararlanma ve kullanımını sağlayan hak"tır (Öztek, Selçuk. "Son Değişikliklerden Sonra Türk Patent Hukukunun Anahatları”, Marmara Üniversitesi Avrupa Topluluğu Enstitüsü Avrupa Araştırmaları Dergisi, C. 4, S. 1-2, 1995-1996, (s.55-63), s.55). 
Patent hakkı, buluş sahibine, buluştan yararlanma ve kendi izni olmadan üçüncü kişilerin haksız fiil ve davranışlarına, tecavüzlerine karşı koyma, bu davranışların önlenmesini isteme imkanı tanıyan bir haktır ${ }^{23}$. Dolayısıyla patent hakkı sahibi, ürünler ister ithal ister yerli üretim olsun buluşun teknoloji alanı, yeri farketmeksizin patent hakkından yararlanabilecek; patentten doğan hakkına izinsiz olarak yapılmış fiillerin de önlenmesini talep edebilecektir ${ }^{24}$ (SMK m. 85/12).

Patent hakkının süresi, başvuru tarihinden başlamak üzere, yirmi yıldır ${ }^{25}$. Sağlanan koruma süresiz olmadığı gibi, sürenin uzatılması da mümkün değildir (SMK m. 101/1). Y1llık ücretler düzenli bir şekilde ödense bile azami süre dolunca patentli buluş, toplumun malı olur (SMK m. 140/2) ve artık buluş sahibi (inhisari haklar bakımından) haksız rekabet hükümlerine de dayanamaz ${ }^{26}$.

Burada inceleyeceğimiz buluşla ve patentle ilişkili hakların hangi unsurlardan oluştuğuna ilişkin bir belirleme yapmak gerekirse, buluşun gerçekleştirilmesinden patentin verilmesine kadar geçen süreç şu şekilde işlemektedir ${ }^{27}$ : Öncelikle buluşun gerçekleştirilmesiyle buluş üzerinde, buluşçu haklarından olan patent isteme hakkı doğar ${ }^{28}$. Bir başka ifadeyle, buluşu gerçekleştiren kişi buluşu için henüz patent başvurusu yapmamışsa burada beklenen bir hak söz konusudur ve şahsı üzerinde mevcut bir hak ortaya çıkar ${ }^{29}$. Yine bu noktada, patent başvurusunda bulunulan ve fakat henüz patent alınmamış aşama, yani başvuru aşaması bulunmaktadı ${ }^{30}$. Bu aşamada ortaya çıkan hak, başvurudan doğan hak (patente yönelik hak) şeklinde de ifade edilmektedir ${ }^{31}$. Nitekim, patent isteme hakkı ve patente yönelik hak kavramları, buluşçu hakkının bir parçası olup, benzer anlamda kullanılmaktadır. Son aşama ise, patent başvurusu üzerine, patentin tescil edildiği ve buluşa patent belgesi verildiği aşamayı ifade etmektedir ve patentten doğan hak kavramıyla ifade edilmektedir ${ }^{32}$.

\section{Buluşla İlgili Hakların Kapsamı}

\section{Genel Olarak}

Yukarıda yer verdiğimiz üzere çalışmamızın konusunu teşkil eden patent ve patent alınması sürecindeki buluşla ilgili haklar incelenecektir. Bu itibarla buluşçu hakkı kapsamında, patent isteme hakkı ile başvurudan doğan hak ve patentten doğan hak şeklinde bir sınıflandırma yapılmıştır. Bu kavramlara, konunun kapsamı dışına çıkmamak adına kısaca yer vereceğiz.

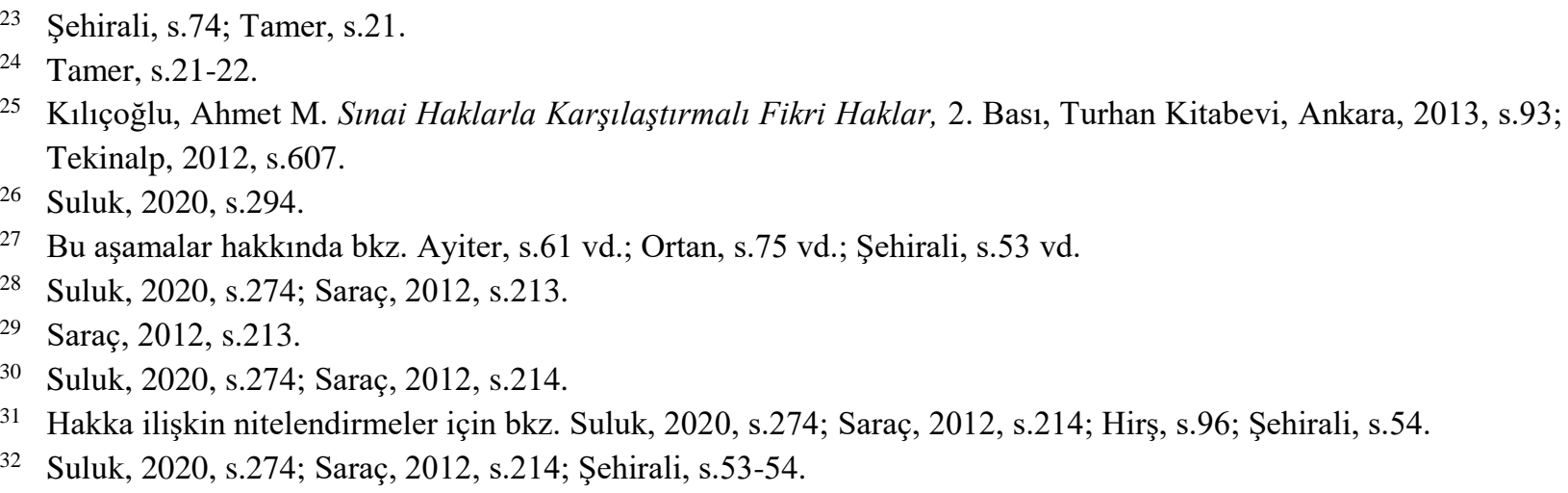




\section{Patent Belgesi Alınmadan Önceki Dönemdeki Buluşla İlgili Haklar}

\section{a. Genel Olarak}

Buluşun yapılmasıyla beraber buluşu yapan kişi üzerinde kendiliğinden bir hak doğar ${ }^{33}$. Söz konusu buluşun yapılmasıyla buluşa patent verilmesinden önce buluş sahibinin şahsında doğan doğal hak, buluşçu hakkı olarak ifade edilmektedir ${ }^{34}$.

Buluşçu hakkı, geniş anlamda ve dar anlamda buluşçu hakkı şeklinde ikili bir ayrıma tabi tutulur $^{35}$. Geniş anlamda buluşçu hakkı, buluş sahibinin buluşu üzerinde doğal bir hakkı ve patent alma konusunda beklenen bir hakkı olduğunu ifade eder ve buluş sahibine buluşundan doğan hakların genel hükümler çerçevesinde korunması yetkisini verir. Dar anlamda buluşçu hakkı ise buluşların, henüz patent vasfina sahip olmasalar da patent mevzuatınca korunmasına, patent izninin verilmesini talep etmeye, her türlü mecrada buluşu üzerinde isminin belirtilmesini istemeye ve buluşa yönelik saldırıların önlenmesini isteme imkanı tanır. Buluşçu hakkı, buluş sahibine, buluşu üzerindeki hakları inhisarî bir biçimde kullanma yetkisini ihtiva etmez ${ }^{36}$.

Doktrinde dar anlamda buluşçu hakkı kapsamında yer alan patente yönelik hak kavramı; patent verilmesinden önceki aşamaya ilişkindir ve iki ayrı hak içeren üst bir kavramı ifade etmektedir ${ }^{37}$. Burada, buluş sahibinin buluşunun tescil edilmesini isteme hakkı ve patent başvurusu üzerinde doğan sübjektif bir kamu hakkı mevcuttur ${ }^{38}$. Patente yönelik hakkın unsurları SMK m. 109 'da patent başvurusundan önceki dönemdeki hakk1 ifade etmek üzere "patent isteme hakkl" olarak $^{39}$, patent başvurusunun yapılmasından sonraki hakkı ifade etmek için de m. 89 ve m. 90 vd. ${ }^{40}$ gibi çeşitli maddeler ve özellikle Yönetmelik m. 130 "patent başvurusu” şeklinde hüküm altına alınmıştır. Nitekim, Yönetmelik m. 130'a göre sınai mülkiyet hakkına ilişkin hukuki işlemlere dair ortak hükümlerin, yani Yönetmelik m. 125-129 hükümleri ile lisansa ilişkin hükümlerin, sınai mülkiyet hakkı başvurularında da uygulanacağı ifade edilmektedir. Anılan hüküm açıkça "patent başvurusu"nun da hukuki işlemlere konu olabileceğini ve dolayısıyla haczinin mümkün olabileceğini ortaya koymaktadır.

Aşağıda sırasıyla patente yönelik hak kapsamında yer alan patent isteme hakkına ve patent başvurusundan doğan hakka (patent başvurusuna) yer vereceğiz. Bu yapılırken hak sahipliği ve türlerine de işaret edeceğiz.

33 Ayiter, s.63; Şehirali, s.54.

34 Ortan, s.77; Sehirali, s.54.

35 Sehirali, s.54.

36 Şehirali, s.55; Ayiter, s.63.

37 Taş Korkmaz, Hülya. İflâs Masası, Yetkin Yayınları, Ankara, 2010, s.179.

38 Hirş, s.96; Şehirali, s.54; Saraç, Tahir. Patentten Doğan Hakka Tecavüz ve Hakkın Korunması, Seçkin Yayıncılık, Ankara, 2003, s.27; Taş Korkmaz, 2010, s.179.

39 SMK m. 109/1'e göre patent isteme hakk1, buluşu yapana ya da haleflerine aittir ve devredilebilir.

40 PatKHK m. 86/1'de patent başvurusu üzerindeki hakkın tesisini ifade etmek amacıyla, patent başvurusu veya patentin başkasına devredilip, miras yolu ile intikal edebileceğini, patent üzerindeki kullanma hakkının lisans konusu olabileceği ve patent başvurusu veya patentin rehnedilebileceği düzenlenmişti. Bu hükme paralel hüküm "sınai mülkiyet hakkı" (SMK m. 2/1-1] esas alınarak ortak hükümler kısmında hukuki işlemler başlığı altında SMK m. 148/1'de "Sinaî mülkiyet hakkl, ...... haczedilebilir veya diğer hukuki işlemlere konu olabilir" şeklinde düzenlenmiştir. 


\section{b. Patent İsteme Hakkı}

Patent isteme hakkı, buluşun yapılması ile patent başvurusu arasındaki sürede söz konusu olan, patent başvurusundan doğan hak ise buluşçunun patent başvurusu yapıp henüz patent iznini almadığı dönemde sahip olduğu hakkı ifade eder ${ }^{41}$. Patente yönelik haklar, ekonomik olarak değerlendirilebilen mali hakları ve buluşu yapan kişinin buluşunu kamuya açıklayıp açıklamamasını ifade eden buluşun alenileşmesini veya patent alınması halinde patent üzerinde isminin belirtilmesini içeren manevi nitelikteki hakları içerir ${ }^{42}$.

Patent isteme hakkının kapsamına buluşu yapan kişiye (buluşcuya) SMK m. 109 ile verilen patent başvurusuna yönelik beklenen hakkı, SMK m. 90/6 uyarınca buluşu yapan ya da yapanların "buluşu yapan" olarak tanınmasıyla adının belirtilmesi için başvuru ya da patent sahibinden isteme hakk1 ${ }^{43}$, SMK m. 111 çerçevesinde haksız bir biçimde patent başvurusunda bulunana karşı dava açma hakkı ve SMK m. 87 ile buluş üzerinde önceki kullanımdan doğan hak girmektedir ${ }^{44}$.

\section{c. Patent Başvurusundan Doğan Hak}

Patent başvurusu, başvuru sahibine patente oldukça yakın bir koruma sağlar. Nitekim, SMK m. 97/4'de patent başvurusundan doğan hakkın kapsamı belirlenmiş ve "Kanun hükümlerine göre patente sağlanan koruma, patent başvurusunun Bültende yayımlandı̆̆ tarihten itibaren, başvuru sahibine geçici olarak tanınır" denilmek suretiyle patent başvurusu patent ile özdeş bir korumaya tabi tutulmuştur ${ }^{45}$. Hatta aynı maddenin beşinci fikrasına göre, başvurudan ve kapsamından haberdar olup, bunu başvuru sahibinin izni olmaksızın kullanan kişilere karşı koruma, başvurunun yayımlanmasından önceki dönemi de kapsayacaktır (SMK m. 97/5).

\section{d. Hak Sahipliği ve Türleri}

Genel olarak hak sahipliğine ${ }^{46}$ ilişkin hükümler SMK m. 109 vd.'da yer almaktadır. Patent isteme hakkı, buluşu yapana veya onun haleflerine ait olup bu hakkın başkalarına devri ve hukuki işlemlere konu olması mümkündür. Buluşun bir kişi tarafindan tek başına gerçekleştirilmesi durumunda bu kişi patent isteme hakkına ve ileride patent hakkına sahip olacaktır ${ }^{47}$. Buluş birden çok kişi tarafından birlikte gerçekleştirilmişse patent isteme hakkı, taraflar aksini

41 Şehirali, s.56.

42 Ortan, s.88; Tekinalp, 2012, s.568.

43 Kaya, 1997, s.174.

44 Saraç, 2012, s.213.

45 Saraç, 2012, s.214; Tekinalp, 2012, s.600.

46 Patente yönelik hakkın sahibinin belirlenmesinde başvuru prensibi ve gerçek buluşçu prensibi öne çıkmaktadır. Başvuru ilkesine göre buluşu gerçekleştirip gerçekleştirmediği dikkate alınmaksızın patent için başvuran kişiye patent hakkı verilir (Ayiter, s.62; Hirsch, C. I, s.125). Gerçek buluşçu ilkesine göre ise buluşu yapan kişilerin buluşu gerçekleştirdikleri anda kişiliklerinde doğan hak gerçek buluş sahipliği ilkesi çerçevesinde kazanılmış sayılır (Ayiter, s.61; Hirş, s.126). Bu nedenle patente yönelik hak sahipliği ilk ve gerçek buluşçuya veya onun haleflerine aittir (Erdem, s.54; Saraç, 2012, s.213-214; Şehirali, s.56; Tamer, s.21). Sınai Mülkiyet Kanunu'na göre, gerçek hak sahipliği ilkesi benimsenmiştir. Dolayısıyla patent hakkı, gerçek hak sahibi olması kaydıyla ilk başvuran kişiye tanınmaktadır. Önceki mevzuat döneminde hak sahipliği ilkesine ilişkin yapılmış tartışmalar için bkz. Ayiter, s.62-63; Hirsch. C. I, s.129; Saraç, Tahir. "551 Sayılı KHK’nin 11. Maddesine Göre Patent İsteme Hakkı ve Hakkın Sahibi”, Prof. Dr. Hayri Domaniç'e 80. Yaş Günü Armağanı, Seçkin Yayınları, İstanbul, 2001, s.529; Tekinalp, 2012, s.556; Şehirali, s.65; Suluk, 2020, s.248.

47 Tekinalp, 2012, s.557. 
kararlaştırmamışlarsa buluşu gerçekleştirenlerin tamamına aittir. Bağımsız buluşçular tarafından gerçekleştirilmesi halinde ise, patent isteme hakkı, ilk yapılan başvurunun yayımlanması önce başvuru yapana aittir. Dolayısıyla patent isteme hakkının, ilk başvuran kişiye ait olduğu kural olarak kabul edilir. Bu kabul, aksinin ispat edilmesine kadar geçerli olur ${ }^{48}$.

Buluşun birden fazla kişi tarafından gerçekleştirilmesi durumunda patente yönelik hak üzerinde birden fazla hak sahibi bulunur. Bu duruma, birlikte buluş sahipliği denir ve ileride patente dönüşecek patente yönelik hak üzerinde aksi kararlaştırılmadıkça müştereken hak sahipliği vardır $^{49}$. Bir başka ifadeyle patent başvurusu ya da patent, tek kişiye ait değilse, hak üzerindeki ortaklık, mevcutsa, taraflar arasındaki anlaşmaya; mevcut değilse Türk Medeni Kanunu'ndaki paylı mülkiyet hükümlerine göre tayin edilir (SMK m. 112/1). Paylı mülkiyet hükümlerinin uygulandığı durumda hak sahiplerinin kendi payları üzerinde tasarruf hakkı vardır (SMK m. 112/1-a) $)^{50}$. Ancak, buluşun kullanımı için üçüncü kişilere lisans verilebilmesi, tüm hak sahiplerinin onayıyla gerçekleşebilir (SMK m. 112/2) ${ }^{51}$. Üzerinde birden çok kişi hak sahibi olsa da, patent başvurusu ya da patentin devri/bölünmesi olanaksızdır (SMK m. 112/3). Yani, anlaşma olmaması halinde paylı mülkiyet hükümlerinin uygulanabilirliği söz konusu olsa da bir bütün olarak patent devri veya üzerinde hak tesisi işleminin ve patent başvurusunun yapılması, oy birliğiyle aksi kararlaştırılmadıkça, bütün paydaşların kabulüne bağlıdır (TMK m. 692).

Ortak buluş hakkındaki açıklamalara ek olarak çalışan buluşlarına da kısaca değinmekte fayda vardır. Bu bağlamda çalışan buluşları, özel hukuk sözleşmesiyle ya da benzer bir ilişki gereğince, başkasının hizmetinde olan ve bu hizmet ilişkisini işverenin gösterdiği belli bir işle ilgili olarak kişisel bir bağımlılık içinde ona karşı yerine getirmekle yükümlü olan kişilerin ve kamu görevlilerinin (yani çalışanın, SMK m. 2/1-d), bir işletme veya kamu idaresinde yükümlü olduğu faaliyeti gereği gerçekleştirdiği ya da büyük ölçüde işletme veya kamu idaresinin deneyim ve çalışmalarına dayanarak, iş ilişkisi sırasında yaptığı buluşları (yani, hizmet buluşu, SMK m. 113/1) ve dolayısıyla kazandıkları manevi ve mali haklarının kanuni düzenlemelerle korunmak suretiyle çalıştıran ya da işletme sahibinin patent hakkının sahibi kabul edilmesini konu eder ${ }^{52}$. SMK m. 113-122 arasında çalışan buluşları düzenlenmiş olup kanun koyucu sistematiğin temeline "çalışan" kavramını koymuştur.

Sınai Mülkiyet Kanunu'nun 113. maddesinde, çalışan buluşlarında hak sahibi ilkesini ifade etmek amacıyla "hizmet buluşları"53 ve "serbest buluşlar" şeklinde ikili bir ayrım yapılmıştır". Çalıştıran ve çalışan ilişkisi varsa buluş hakkı gerçek buluş sahibi ilkesi uyarınca buluşçunun

48 SMK m. 110 ve m. 111'de patent isteme hakkına ve patente ilişkin gerçek hak sahipliği noktasında hak iddiasında bulunulması (gasp) halinde ne tür işlemlerin yapılacağı ve hangi yollara başvurulabileceği düzenlenmektedir.

49 Şehirali, s.57; Ortan, s.97; Tekinalp, 2012, s.557.

50 Ayrıca bkz.: SMK m. 112/1-b, c, ç.

51 Lisans verilmesi için aranan oybirliği şartı sağlanamazsa mahkemeden, hakkaniyete uygun bir biçimde karar verilmesi istenebilir (SMK m. 112/2).

52 Tekinalp, 2012, s.558-559.

53 Hizmet buluşlarına ilişkin olarak TBK m. 427'de bir hüküm yer almaktadır. Anılan hüküm ise SMK'ya atıf yapmaktadır. Dolayısıyla hizmet buluşlarına ilişkin olarak SMK m.113 ve devamında yer alan hükümler uygulanacaktır.

54 Keskinci, Derya. "Hizmet Buluşları”, Prof. Dr. Ergun Önen'e Armăgan, Alkım Yayınevi, İstanbul, 2003, s.206. 
kişiliğinde doğar ${ }^{55}$. Ancak SMK m. 115 uyarınca işverenin, hizmet sözleşmesi çerçevesinde görev ifa edilirken işçinin gerçekleştirdiği buluş için uygun bir bedel ödeyerek buluş hakkının kendisine devredilmesini isteme hakkı vardır ${ }^{56}$. Çalışan/çalışanlar, hizmet buluşuna konu edilebilecek bir buluş yaptığında, bunu gecikmeksizin, yazılı olarak işverene bildirme yükümlülügüüle karşı karşıyadır. İşveren, bu bildirimin kendisine ulaştığı tarihi, gecikmeden, yazılı olarak bildirimde bulunana bildirir (SMK m. 114/1). İşverenin hizmet buluşu üzerinde kısmi ya da tam hak talep edecekse, bunu, çalışanın bildiriminin kendisine ulaşmasından en geç dört ay içerisinde yine yazılı bir biçimde yapması gerekir (SMK m. 115/1) ${ }^{57}$. İşverenin, tam hak talebini içeren bildiriminin çalışana ulaşmasıyla buluş üzerindeki haklar işverene geçer (SMK m. 115/2). Ancak bu durumda, çalışanın, işverenden makul bir bedel ödenmesini isteme hakkı vardır (SMK m. 115/6) ${ }^{58}$.

Buluş üzerindeki hak sahipliği konusunda, tarafların sözleşme yapmış olmaları da ihtimal dahilindedir ${ }^{59}$. Ancak bu durumda çalışan ile işveren arasında yapılmış olan sözleşme hükümleri hem çalışanın korunması ilkesi çerçevesinde hem de SMK m. 117 çerçevesinde değerlendirmeye tabi tutulacaktır. Bu bağlamda, işverenlerin SMK'nın çalışan buluşlarına ilişkin hükümlerine aykırı olacak şekilde çalışanların aleyhine hareket etmesi mümkün değildir. Taraflara bu konuda tanınmış olan serbesti, hizmet buluşlarında patent verilmesi amacıyla yapılan başvurudan; serbest buluşlarda, çalışanın işverene yapacağı bildirim yükümlülüğünden sonra başlayacaktır (SMK m. 117/1).

Hizmet buluşu kavramına dahil edilmeyen buluşlar, serbest buluş olarak nitelendirilir (SMK m. 113/2) ${ }^{60}$. Serbest buluş hakkı tamamen çalışana aittir ve işverenin irade açıklaması suretiyle hak sahibi olması mümkün değildir ${ }^{61}$. Ancak, SMK m. 119 çerçevesinde çalışan, iş sözleşmesi kapsamındayken bir serbest buluş yaparsa, buluş ve gerekiyorsa buluşun gerçekleştirme şeklini de içerecek şekilde gecikmeksizin işverene bildirmelidir.

Çalışan buluşlarına ilişkin hükümler, kural olarak yüksek öğretim kurumlarında geliştirilen buluşlara da uygulanır. Ancak bu kurala özel kanun hükümleri ve SMK'nın 121. maddesiyle iki istisna getirilmiştir. Konuya ilişkin olarak öncelikle varsa özel kanun hükümleri, (örneğin 6550 sayılı Kanun), yoksa SMK m. 121 hükümleri uygulanacaktır. SMK m. 121'de de hüküm bulunmuyorsa, SMK m. 113-120 hükümleri devreye girecektir.

Bir yükseköğretim kurumunda yapılan bilimsel çalışma ve araştırma sonucunda ortaya buluş çıkarsa, buluşu yapan bunu gecikmeksizin, yazılı olarak yükseköğretim kurumuna bildirmekle yükümlüdür. Şayet patent başvurusu yapılmışsa, bu da ilgili kuruma bildirilir. Yükseköğretim kurumu buluş üzerinde hak sahipliğini ileri sürecekse, patent başvurusunu yapma

55 Hirsch, C. I, s.138; Saraç, 2012, s.217; Tekinalp, 2012, s.561.

56 Ortan, s.143.

57 Hizmet buluşu, böyle bir bildirim yapılmaz ya da hak talep edilmezse, serbest buluş niteliği kazanır (SMK m. 115/1-c.3).

58 Kısmi hak talep edilirse, buluşu kullanan işverenin, talebi halinde çalışana makul bir bedel ödemesi gerekir (SMK m. 115/6-c.2)

59 Buluşun yapılması ve hizmet buluşlarında işverene bildirimi ile serbest buluşlarda iyileştirme tekliflerinin yapılmasından önce sözleşme yapılamaz, Tekinalp, 2012, s.559.

60 Ayiter, s.69; Erdem, s.205; Noyan, Erdal. Patent Hukuku, 2. Bask1, Adalet Yayınevi, Ankara, 2011, s.198.

61 Tekinalp, 2012, s.565. 
yükümlülüğüyle karşı karşıyadır. Aksi durumda buluş, serbest buluş niteliği kazanacaktır (SMK m. 121/2). Buluştan bir gelir elde edilmesi halinde, elde edilen meblağ, buluşu yapana en az üçte bir oranında pay verilmesi kaydıyla kurum ile paylaşılır (SMK m. 121/8).

Ayrıca kamu destekli projelerde ortaya çıkan buluşlar hakkında SMK m. 122'de düzenlemeler yer almaktadır. Bu hüküm kapsamında, buluşçu ve proje sahibi farklı süjeler olduğu için çalışan ve buluşçu kavramları hiç kullanılmamıştır. Nitekim, konu çalışan buluşları ile ilgili de değildir ${ }^{62}$. Bu sebeple çalışan buluşlarına ilişkin olarak SMK m. 113 vd. hükümleri burada uygulanmayacaktır.

Kamu kurum ve kuruluşlarının desteklediği projelerde, buluşun destek sağlayan kamu kurumuna bildirilmesi şarttır. Bildirimin yapılmasından sonraki bir y1l içerisinde proje desteğinden faydalanan kişinin, buluşu üzerinde hak sahipliği talep edip etmediğini yazılı olarak bildirmesi gerekir. Destekten faydalanmış kişinin, bir yıl içerisinde hak sahipliğini talep etmemesi ya da buna ilişkin tercihini kuruma bildirmemesi halinde, destek vermiş olan kurum, buluşun hak sahipliğini alabilir (SMK m. 122/1). Proje desteğinden faydalanıp buluş gerçekleştiren kimse, hak sahipliği talep etse de, ilgili kurum, sözleşmede belirtilerek feragat edilmemişse, buluşun kendi ihtiyaçları için kullanımına ilişkin bedelsiz bir lisans hakkına sahip olabilir (SMK m. 122/4).

\section{Patentten Doğan Hak}

Patentten doğan hak kavramı, patent başvurusunun Türk Patent ve Marka Kurumu (TÜRKPATENT) nezdinde olumlu sonuçlanmasıyla patent belgesinin verilmesi ile kazanılan ve patent konusu üzerinde, sahibine inhisarî biçimde tam yararlanma yetkisi veren mutlak haktır ${ }^{63}$. Bu itibarla, patent hakkı sahibinin yararlanma yetkisi olumlu, patent üzerindeki haklarının 3. kişilerce haksız biçimde kullanılmasını önlemek şeklinde olumsuz nitelikte yetkiden söz edilirr ${ }^{64}$.

Patent hakkından doğan olumlu etki, patent üzerinde sahibine, inhisari yararlanma ve patentin ekonomik anlamda değerlendirilmesi ve patentten kazanç sağlanması için gerekli işlemlerin yapılmasını kapsayan "kullanma" yetkisini tanır ${ }^{65}$.

Patentten doğan hakkın olumsuz etkisi ise patent hakkından doğan kullanma ve yararlanma yetkisine tecavüz edilmesi şeklinde somutlaşan fiilleri men etme yetkisidir ${ }^{66}$.

Patent verilerek hakkı tescil edilmiş olan, patentten doğan hakkın sahibidir. Kural olarak patent üzerindeki hak patente yönelik hak sahibinindir. Patente yönelik hak sahibinin buluşuna patent verilmesini isteme hakkı, patent belgesi alındıktan sonra, patentten doğan hak kapsamına girer. Patentten doğan hak SMK m. 148/1 ve SMKY m. 125 vd. uyarınca devir, haciz, mirasla intikal gibi hukuki işlemlere konu olabilmesi bakımından patente yönelik haklarla benzerlik gösterdiğinden, patente yönelik hakkın hukuki işlemlere konu olup hak sahipliği bakımından bir

62 Suluk, 2020, s.259.

63 Saraç, 2003, s.29.

64 Hirsch, C. I, s.177; Saraç, 2003, s.29; Şehirali, s.74

65 Tekinalp, 2012, s.601.

66 Tekinalp, 2012, s.601. 
farklılık yoksa, patente yönelik hak sahibi patentten doğan hakkın da sahibi konumuna gelecektir ${ }^{67}$.

Çalışmamız bağlamında patent hakkının haczi inceleneceğinden patent isteminin neye ilişkin olduğu, ürün patenti yahut usul patentinden doğan hakkın tanımlanmasıyla patentten doğan hakkın kapsamındaki fiillerin değerlendirilmesi gerekir.

Ürün patentinden doğan haklar, patent konusu ürünün üretimi, satımı, ithali, kullanımı ve tüm bu amaçlar doğrultusunda ürünün elde bulundurulmasıdır (SMK m. 85/2-a) ${ }^{68}$. Ayrıca, üçüncü kişilere, "özel maksatla sınırlı" bir kullanım hakkı tanınabilir.

Buluş olma vasfına haiz olan, patent alınmış bir usul üzerindeki hakka, usullere ilişkin patentten doğan hak denir. Bu hak; patent konusu buluş bir usule ilişkinse, usulün kullanımı ve kullanımın teklifi ile usulden doğrudan doğruya elde edilmiş ürünün kullanımı, satış için sunulması, ithali ve bu amaçların dışında elde bulundurulması hakkını içerir (SMK m. 85/2-b, c, ç) $)^{69}$.

\section{PATENT HAKKININ HACZİ}

\section{A. Genel Olarak}

İcra ve İflas Kanunu'na (İIK) göre, bir haciz prosedürü başlatıldığında, takip talebinde bulunulur ve icra dairesi, borçluya ödeme emri gönderir. Ödeme emrinin kesinleşmesine rağmen borç ödenmezse, alacaklının talebiyle borçlunun borcuna yetecek miktarda haczi caiz malı, hak ve alacakları icra dairesi tarafından haczedilebilir.

İcra ve iflas hukukunda alacaklının parayla tatmin edilmesi kuralı geçerlidir ${ }^{70}$. Yani, alacaklı, alacağına karşılık olarak borçlunun haczedilen mallarının satılması sonucunda elde edilen parayı alır. Dolayısıyla haciz; kesinleşmiş bir icra takibine konu olan belli miktarda para alacağının ödenmesini sağlamak için, alacaklının talebi ile alacağı karşılayacak miktarda borçlunun mal ve haklarına icra dairesince hukuken el konulması olarak tanımlanır ${ }^{71}$. Haciz, fiilen el koyma şeklinde olabileceği gibi, hukuken el koyma şeklinde de olabilir. Örneğin, altın, gümüş, kıymetli evrak ve

67 Şehirali, s.85; Demirci, Aylin. Gayrimaddi Malların Haczi ve Paraya Çevrilmesi, Yayımlanmamış Yüksek Lisans Tezi, Ankara Üniversitesi Sosyal Bilimler Enstitüsü, Ankara, 2002, s.56.

68 Şehirali, s.90 vd.

69 Demirci, s.56; Şehirali, s.94; Arı, M. Haluk. Patent Lisansı Anlaşmalarında Münhasırlık ve Bölgesel Sınırlamalar, Rekabet Kurumu, Ankara 2003, s.15.

70 Üstündağ, Saim. İcra Hukukunun Esaslarl, 8. Bas1, İstanbul 2004, s.140; Kuru, Baki. Ícra ve İflâs Hukuku El Kitabl, 2. Bask1, Adalet Yayınevi, Ankara 2013, s.410 (Kuru, El Kitabı); Kuru, Baki. Istinaf Sistemine Göre Yazılmış İcra ve İflas Hukuku, Legal Yayıncılık, İstanbul, 2016, s.207 (Kuru, İcra).

71 Postacıoğlu, İlhan E. / Altay Sümer. İcra Hukuku Esasları, Genişletilmiş 5. Bası, Vedat Kitapçılık, İstanbul, 2010, s.359; Üstündağ, s.143; Kuru, El Kitabı, s.410; Kuru, Baki / Arslan, Ramazan/ Y1lmaz, Ejder. Ícra ve Iflas Hukuku Ders Kitabı, 28. Bask1, Yetkin Yayınları, Ankara, 2014, s.231; Yıldırım, Kamil/ Deren-Yıldırım, Nevhis. Ícra Hukuku, 5. Bask1, Beta Yayınevi, İstanbul, 2012, s.134; Karsl1, Abdurrahim. İcra ve Iflas Hukuku, 3. Bask1, Alternatif Yayınc1lık, İstanbul, 2014, s.278; Muşul, s.505; Pekcanıtez, Hakan/Atalay, Oğuz/Sungurtekin Özkan, Meral/Özekes, Muhammet, İcra ve Iflas Hukuku, 10. Bası, Ankara 2012 (Pekcanıtez/Atalay/Sungurtekin Özkan/Özekes), s.266; Arslan, Ramazan /Yılmaz, Ejder / Taşpınar Ayvaz, Sema /Hanağası, Emel. İcra ve Iflas Hukuku, 6. Baskı, Yetkin Yayınları, Ankara, 2020, s.253; Kuru, İcra, s.207; Atal1, Murat / Ermenek, İbrahim /Erdoğan, Ersin. Ícra ve Iflas Hukuku, 3. Bası, Yetkin Yayınları, Ankara 2020, s.185. 
paranın fiilen el koyma suretiyle haczi gerekir (İ̈K m. 88). Bunların dışındaki taşınır malların haczedilmiş sayılması için icra müdürünün hukuken el koyması yeterlidir. Yani, icra memurunun, haczettiği taşınır mallar alacaklının muvafakatiyle istenildiği zaman verilmesi koşuluyla muvakkaten borçluda bırakabilir ya da yediemine teslim edilebilir (İ̈K m. 88) ${ }^{72}$.

Haciz için yetkili icra dairesi icra takibinin yapıldığı icra dairesidir ${ }^{73}$. Haczedilecek mallar takibin yapıldığı icra dairesinin görev alanı dışındaysa malların olduğu yer icra dairesi, talimatla istinabe edilir (İIK m. 79/2). Fakat resmi sicile kayıtlı olan mallar takibin yapıldığı icra dairesince fiilen (mahalline gidilerek) haczedilebileceği gibi kaydına işletilmek suretiyle kayden de haczedilebilecektir. Yine 7251 sayılı Kanun m. 49 ile İIK m. 78/1'de yapılan değişiklik çerçevesinde "alacaklı dilerse haciz talebinde bulunmaksızın Ulusal Yargl A $\breve{g}$ l Bilişim Sistemi üzerinden, bu sisteme entegre bilişim sistemleri vasitasıyla borçlunun mal, hak veya alacağını sorgulayabilir ve bu sorgulama sonunda Uyap Sistemi, varsa borçlunun mal, hak veya alacağının mahiyeti ve detayı hakkında bilgi verir ve bu durumda sistem üzerinden de haciz talep edilebilir. Bu takdirde icra dairesi, tespit edilen mal, hak veya alacă̆l elektronik ortamda haczeder'. Dolayısıyla elektronik ortamda varlığı tespit edilen mal, hak ve alacakların, icra dairesi tarafından elektronik ortamda haczi mümkün hale gelmiştir. Bu değişiklik, sokağa çıkma yasakları da dahil olmak üzere birçok tedbirin alındığı Covid-19 salgın dönemi göz önüne alındığında, isabetli bir değişiklik olmuştur. Öte yandan borçlunun mal varlığı unsurlarının elektronik ortamda kaydının bulunması ve bu tarz haczin mümkün olması, icra takibinin daha hızlı, basit ve ucuz olarak gerçekleşmesine, yani takip ekonomisi ilkesine uygunluğun sağlanmasına önemli derecede katk1 sağlayacaktır. Patent hakkına ilişkin haciz de elektronik ortamda gerçekleştirilebilecek niteliktedir ${ }^{74}$.

Haciz işlemini icra müdürü veya icra memurunun malların mahalline giderek haciz tutanağı düzenlemesiyle yapılır (İ̈K m. 102). Haciz tutanağı haczedilen malların tek ispat vasıtasıdır $^{75}$. Taşınır veya taşınmaz malların dışında haczedilen hakların (özellikle gayri maddi mallar üzerindeki hakların) haczinde de tutanağın düzenlemesi gerekir. Hatta haczedilen bütün malvarlığı unsurlarının haczedildiğinin haciz tutanağında gösterilmesi gerekir; zira haciz tutanağ haczedilen malların haczedildiğinin tek ispat $\operatorname{aracıdır}^{76}$.

Haczin yapıldığı anın nasıl belirleneceği konusu da önem arz eder. Fakat bu konu doktrinde tartışmalıdır. Bir görüşe göre ${ }^{77}$ haczin yapılması için icra müdürünün iradesini açıklaması gerekmekte, ancak bu haciz iradesinin açıklanmasının (haricileşmesi), haciz sırasında mevcut

72 Pekcanıtez/Atalay/Sungurtekin Özkan/Özekes s.291; Kuru, El Kitabı, s.427; Kuru/Arslan/Yılmaz, s.239-241; Arslan/Yılmaz/Taşpınar Ayvaz, s.259; Kuru, İcra, s.215; Atalı/Ermenek /Erdoğan, s.217.

73 Yıldırım/Deren-Yıldırım, s.134; Kuru, El Kitabı, s.416; Kuru/Arslan/Yılmaz, s.233; Üstündağ, s.144; Arslan/Yılmaz/Taşpınar Ayvaz, s.249; Kuru, İcra, s.210; Atalı/Ermenek /Erdoğan, s.193.

74 Bu konuya aşağıda patent hakkının kapsamında yer alan haklara ilişkin haciz incelenirken ayrıca değinilecektir.

75 Kuru, El Kitabı, s.424; Kuru/Arslan/Yılmaz, s.237; Arslan/Yılmaz/Taşpınar Ayvaz/Hanağası, s.253; Pekcanıtez/Atalay/Sungurtekin Özkan/Özekes, s.270; Kuru, İcra, s.213; Atalı/Ermenek /Erdoğan, s.33.

76 Arslan/Yılmaz/Taşpınar Ayvaz/Hanağası, s.253; Kuru/Arslan/Yılmaz, s.237; Kuru, El Kitabı, s.424; Pekcanıtez/Atalay/Sungurtekin Özkan/Özekes, s.270.

77 Üstündağ, s.147-148; Muşul, Timuçin. İcra ve İflas Hukuku, 6. Bask1, Ankara 2013, s.506; Postacıoğlu/Altay, s.361-365. Bir görüss, haciz iradesinin açıklanması anının, hacizde borçlu hazır bulunuyorsa tutanağın tutulduğu, aksi halde İIK m. 103'deki davetiyenin tebliğ anı olduğunu ifade etmektedir (Yıldııım/Deren-Yıldırım, s.138). 
bulunan borçlu veya onun adına tebligatı kabule yetkili kişi karşısında yapılmış olması gerekir. Eğer haciz yapılırken borçlu yoksa ve borçlu adına tebligatı kabule yetkili kişiler de bulunmuyorsa, haciz iradesi, hazır bulunmayan borçlu veya borçlu adına tebligatı kabule yetkili kişilere İIK m. 103 gereğince icra müdürünce ulaştırıldığında, haciz tamamlanmış olur. Bizim de katıldığımız bir diğer görüşe göre ${ }^{78}$ ise, haciz, icra müdürünün hacze ilişkin iradesinin haciz tutanağına geçirilmesiyle tamamlanır. Haciz konusu mallar ister kayden ister fiilen haczedilmiş olsun icra müdürünün haciz tutanağı düzenlemesi gerekir. İcra müdürünün haciz tutanağı düzenlediği anı haczin yapıldığı an olarak kabul etmekteyiz. Haczin yapılma anının tespiti, bu andan itibaren borçlunun hacizli mal ve haklar üzerindeki tasarrufunun sınırlanması bakımından önemlidir ${ }^{79}$; yine, varsa başka alacaklıların, haczin yapıldığı andan itibaren, şartları oluşmuşsa ilk hacze iştirak edebilme veya bu imkan yoksa, arta kalan değerlerle tatmin edilebilmesi için de önem arz etmektedir ${ }^{80}$.

SMK m. 148/1'de ${ }^{81}$ yer alan hükme göre, sınai mülkiyet hakkının haczedilmesi mümkündür. Hükümde ifade edilen sınai mülkiyet hakkının kapsamına patent hakk1 da dâhil olmaktadır (SMK m. 2/1,1). Benzer düzenleme SMKY m. 126'da da yer almaktadır. Anılan hükme göre "marka, tasarım ve patent işletmeden bă̆ımsız olarak haczedilebilir. Haciz, Sicile kaydedilir ve Bültende yayımlanır". Bu çerçevede, patent hakkının da haczi caiz olan malvarlığı unsurları arasında yer aldığı anlaşılmaktadır.

\section{B. Haczin Konusu}

Haczin konusuna borçlunun taşınır ve taşınmaz malları, üçüncü kişilerdeki alacakları ve diğer malvarlığı hakları dâhil edilmektedir ${ }^{82}$. Başka bir ifadeyle borçluya ait olan maddi bir değere sahip tüm malvarlığı unsurları haczin konusunu oluşturur.

Doktrinde de ifade edildiği üzere borçlunun mal beyanında bulunurken "ücret alacaklarını, tazminat alacaklarını, haksız fiilden doğan alacaklarını, tek taraflı ya da çift taraflı hukuki ilişkilerinden, sözleşmelerden, mirastan doğan alacaklarını, nafaka alacaklarını, başkasında olan ve borç ödemeden aciz vesikasına bağlı alacaklarını, gayrimenkuller üzerindeki alacaklarını, şirket hissesi, intifa, rehin ya da hapis haklarını” göstermesi gerektiği ${ }^{83}$ için burada sayılmış tüm alacakların haczin konusunu oluşturabileceğini söyleyebiliriz. Ayrıca, mevcut mal veya haklarla birlikte muaccel alacaklar ile hâlihazırda mevcut olan bir hukuki sebebe dayanılarak ortaya çıkacak olan maaş ve ücret gibi henüz elde edilmemiş değerlerin haczi de caizdir ${ }^{84}$.

78 Karslı, s.293; Topal, Önder. "Senede Bağlanmamış Anonim Şirket Payının Haczi”, Ankara Üniversitesi Hukuk Fakültesi Dergisi Özel Sayı: Prof. Dr. Zeki Hafizoğullarına Armă̆an, C. 65, S. 4, Y. 2016, (s.2977-3016), s.2992; Jäger, Carl. Das Bundesgesetz betreffend Schuldbetreitbung und Konkurs, Band I, Zürich 1911; Band II, Zürich 1911, s.89.

79 Postacioğlu/Altay, s.362.

80 Postacioğlu/Altay, s.362.

81 Alman Patent Kanunu'nda (PatG) § 15 Abs. 1'e göre patent isteme hakk1 ve patentten doğan hak mirasçılara geçer. Sınırlı veya sınırsız başkalarına devredilebilir. Bu durumda hakkın devri ve bu sebeple de haczi de $\$ 857$ Abs. 1'e göre mümkündür (Engelbert, s. 21).

82 Kuru, İcra, s.214; Üstündağ, s.170; Kuru/Arslan/Yılmaz, s.239; Arslan/Yılmaz/Taşpınar Ayvaz/Hanağası, s.258; Pekcanıtez/Atalay/Sungurtekin Özkan/Özekes, s.287; Atal1/Ermenek /Erdoğan, s.185-186.

83 Ansay, S. Şakir. Hukuk İcra ve İflâs Usulleri, İstiklâl Matbaası, Ankara, 1960, s.69-70.

84 Berkin, Necmeddin M. İcra Hukuku Dersleri, 2. Bas1, Hamle Matbaas1, İstanbul, 1969, s.87. 
Patent hakkının haczi konusunu, bu hakkın kapsamına giren patent isteme hakkı ve başvurudan doğan hak ile patentten doğan hak (patent üzerindeki hak) ${ }^{85}$ oluşturmaktadır $^{86}$. Bu itibarla öncelikle buluşçu hakkı; patente yönelik hak kapsamında yer alan patent isteme hakkı ile patent başvurusundan doğan haklar ve nihayet patent alınmasından sonra doğan haklar, yani patentten doğan hak çerçevesinde haczin konusu belirlemeye çalışacağız.

\section{Patent Belgesi Alınmadan Önceki Dönemde (Buluşla İlgili Haklar Kapsamında) Haczin Konusu}

\section{a. Genel Olarak}

Fikri bir çabanın sonucu olarak ortaya çıkan buluşun geçtiği birçok aşama vardır. Buluşçu, buluşun araştırma aşamasında önemli ölçüde çaba göstermektedir ve bu aşamada olan buluşun haczine ilişkin belirli kıstaslar mevcuttur. Öncelikle teknik alana ait bir çözüm olan buluşun diş dünyada varlık kazanması yetmez, yenilik ve sanayiye uygulanabilirlik vasfina da haiz olması gerekir ${ }^{87}$. Yine, halihazırda var olan bir buluşun da vasfinın değiştirilerek uygulanmasını sağlayan, yeni çözüm önerisi getiren bir buluş yapılması da mümkündür. Çeşitli sebeplerle belirli bir ilerleme ${ }^{88}$ sağlamış buluşların üretim aşaması da oldukça uzayabilir. Tüm bu süreçte araştırma ve geliştirme faaliyetlerinin, gerçek anlamda bir buluş olarak nitelendirilemeyeceği veya gerçekleştirilen buluş henüz alenileşmediği ${ }^{89}$ için haczinden de söz edilemez ${ }^{90}$. Zira, bu tarz araştırma aşamasında olan buluş, fikir niteliğindedir ve bir anlamda henüz deneme aşamasındadır ${ }^{91}$. Dolayısıyla henüz kişiliğinin bir parçası durumundadır ${ }^{92}$. Buna ek olarak bu aşamadaki bir buluş çalışmasının maddî bir değer ifade ettiğinden de söz edilemez. Bir şekilde bu aşamada haczin mümkün olduğu kabul edilse de, buluşun haczinden sonra satışı için değer tespitinin yapılması oldukça güç olacaktır.

Öte yandan araştırma aşaması tamamlanmış ancak henüz patent başvurusuna konu olmamış bir buluş ise, ekonomik değere haizdir. Patent başvurusunda bulunulmadan önce buluş sahibinin kişilik haklarına dâhil olan buluşçu hakkı, anılan buluşun alenîleştirilmesiyle ${ }^{93}$

85 Patent hakkını inceleme konusu yaparken patente yönelik hak ve patent üzerindeki hak olmak üzere iki ana başlık altında inceleyenler için bkz. Bolayır, Nur. "Fikri Mülkiyet Haklarında Cebri İcra Sistemi”, Dokuz Eylül Üniversitesi Dergisi Özel Sayl, Prof. Dr. Hakan Pekcanıtez’ e Armăgan, C. I, Y. 2014, İzmir, 2015, (s.2513-2570), s.2528-2530; Demirci, s.62-63; Taş Korkmaz, 2010, s.179.

86 Bu haklara ilişkin genel açıklamalar için bkz. yuk. I ,D.

87 Tekinalp, 2012, s.530.

88 Tekinalp, 2012, s.529.

89 Bolayır, s.2528; Alenileşme, bir toplantı, sempozyum ya da konferans sırasında olabileceği gibi, çeşitli görüşmeler sırasında kamuya açıklanma suretiyle de gerçekleşebilir. Yine, doktrinde, buluşun sadece konudan anlayan tek bir kişiye açıklanmasının da alenileşme şartını sağlamaya yeteceği ifade edilmiştir (Tekinalp, Ünal. "Yeni Patent Hukukunda Buluş Sahibi İlkesi”, İHFM Prof. Dr. Orhan Münir Çağıl'a Armağan Sayısı, 1997, C.LV, S. 4, (s.129136), s.131).

90 Ayiter, s.105; Bolayır, s.2528; Demirci, s.62; Hirsch, C.I, s.179; Tekinalp, 2012, s.628.

91 Bolayir, s.2528-2529.

92 Bolayir, s.2529.

93 Buluş sahibinin buluşuna ilişkin ürünler üretmesi, rehnetmesi, sözleşmesel ilişkiler kurması, üçüncü kişilere münhasıran kullanım hakkı tanıyan lisans vermesi sahibinin buluşunu kullanma isteğini ortaya koymaktadır (Bolayır, s.2529). 
devredilebilir nitelikte bir malvarlığı hakkına dönüşmekte ve bu çerçevede hacze konu teşkil etmektedir ${ }^{94}$.

Bu başlık altında ayrıca çalışan buluşları üzerindeki hakkın ve çalışana buluş sebebiyle ödenecek bedelin haczine de değinmekte fayda vardır. Çalışan buluşlarının hizmet buluşu ve serbest buluş ${ }^{95}$ olmak üzere ikiye ayrıldığı yukarıda ifade edildi ${ }^{96}$. Hizmet buluşlarının aksine serbest buluşlar, tamamen çalışana ait oldukları için bunların haczin konusu bağlamında ayrıca değerlendirilmesine gerek yoktur ${ }^{97}$.

Hizmet buluşu, gerçek buluş sahibi ilkesi gereğince çalışanın şahsında ve malvarlığında doğsa da işverenin buluşu tamamen veya kısmen devralma hakkı vardır (SMK m. 115/1). Bu hak kullanılmak istenirse, yapılacak bildirim çalışana ulaştığında buluş üzerindeki tüm haklar işverene geçmiş olur (SMK m. 115/2). Bu durumda işveren tam hak talebinde bulunursa, buluş üzerinde tam hakimiyet ${ }^{98}$ kurulmasını sağlamaya yarayan ve herkese karşı ileri sürülebilen hak işverene geçmiş olur. Ancak SMK m. 90/6 uyarınca buluşu yapan çalışanın adının belirtilmesine ilişkin manevi hakkı, devir yoluyla işverene geçemez ${ }^{99}$. Dolayısıyla, çalışan buluşlarının üzerindeki hakkın tamamen işverene geçmesi mümkün olduğundan işverene geçen mali hakların haczedilmesi de mümkündür ${ }^{100}$.

İşverenin hizmet buluşu üzerinde tam hak sahibi olması durumunda çalışanın kendisinden SMK m. 115/6 uyarınca isteyebileceği bedelin ${ }^{101}$ cebri icraya konu olmasının mümkün olup

94 Bolayir, s. 2529; Koch, Raphael, Kindl/Meller-Hannich, Gesamtes Recht der Zwangsvollstreckung 4. Auflage 2021, https://beckonline.beck.de/Dokument?vpath=bibdata\%2Fkomm\%2FKinMelWolKoZV_4\%2FZPO\%2Fcont\%2FKinMelWol KoZV.ZPO.p857.glII.gl4.glc.glaa.htm, Erişim Tarihi: 08.03.2021, ZPO § 857, Rn. 20. Alman hukukunda da hakim görüş bu yöndedir (bkz. Engelbert, s. 23-24). Fakat başka bir görüşe göre, PatG $\S 35$ çerçevesinde başvuru yapılmadan önce haczedilebilecek bir hak bulunmamaktadır (Gottwald, Peter, Zwangsvollstreckung, Kommentar zu den $\S \S 704-915$ h ZPO mit Antrags- und Klagemustern für die Rechtspraxis, 5. Auflage, 2005, §857, Rn. 46). Alman hukukunda bu konudaki tartışmalar ve görüşler hakkında ayrıntılı bilgi için bkz. Engelbert, s. 21 -26.

95 Keskinci, s.206.

96 Hizmet buluşu ve çalışan buluşuna ilişkin açıklamalar için bkz. yuk. I, D, 3, b.

$97 \mathrm{Bu}$ kısımda çalışan buluşlarından hizmet buluşunun haczi bağlamındaki açıklamalar, istisnalar dışında, kamu kurum ve kuruluşları çalışanlarının buluşları hakkında da geçerlilik taşıyacaktır (SMK m. 113/4). Ancak işveren konumundaki kamu kurum ve kuruluşlarının patent haklarının haczine ilişkin olarak kendi özel kanunları çerçevesinde ayrıca değerlendirme yapılması gerekecektir. Bu durum ise bu çalışmanın kapsamı dışında kalmaktadır.

98 Ortan, s.123.

99 Demirci, s.53; Taş Korkmaz, 2010, s.182; Tekinalp, 2012, s.515.

${ }^{100}$ Alman hukukunda, kişisel bir hak olarak, işverenin bir hizmet buluşu kullanma hakkının devredilemeyeceği ve bu nedenle haczedilemeyeceği de ifade edilmektedir [Musielak/Voit/Flockenhaus ZPO $§ 857$ Rn. 12 (Musielak, Hans-Joachim/Voit, Wolfgang, Musielak/Voit Zivilprozessordnung mit Gerichtsverfassungsgesetz, 17. neubearbeitete Auflage, München, 2020, https://beckonline.beck.de/?vpath=bibdata\%2Fkomm\%2FMusielakZPOKO_17\%2FZPO\%2Fcont\%2FMusielakZPOKO $\% 2$ EZPO\%2Ep857\%2Ehtm, Erişim Tarihi: 08.03.2021)].

${ }^{101} \mathrm{Bu}$ bedel belirlenirken, hizmet buluşunun ekonomik değerinin, işçinin o görevdeki rolünün, işletmenin buluşun yapılmasındaki payının da dikkate alınacağı hakkında bkz.: Güneş, İlhami. "Türk Patent Hukuku Uygulamasında İşçi (Hizmet) Buluşları, Serbest Buluş Kavramı ve Karşılaştırmalı Hukuk” Ankara Barosu Fikri Mülkiyet ve Rekabet Hukuku Dergisi, Y. 2010 Sa. 2 (s.13-23), s.16. 
olamayacağı konusunda bir değerlendirme yapabilmek için öncelikle ödenecek bedelin niteliğinin ve hangi kriterlere göre belirleneceğinin tespiti gerekir. Çalışan ile işveren, çalışan buluşları konusunda, sözleşme yapma serbestisine sahiptir (SMK m. 117/1). Bu çerçevede bakıldığında çalışan ve işverenin sözleşme serbestîsi çerçevesinde yapacakları sözleşme ile buluş halinde bedel ödenip ödenmeyeceğini, ödenecekse bunun miktarını serbestçe tayin edebilirler. Fakat SMK m. 117/2 bağlamında hizmet buluşları (ile serbest buluşlar) üzerinde yapılacak bu sözleşmelerin ve bedele ilişkin hükümlerinin, emredici hükümlere aykırı olmasa da, önemli ölçüde hakkaniyetle bağdaşmaması halinde, geçersiz sayılmaları gerekir. Dolayısıyla, anılan hüküm kapsamında tarafların kararlaştırdıkları bedelin de hakkaniyete uygun olması şartı getirilmiştir. Sözleşme ve bedel hakkındaki bu kurallara aykırılık halinde, çalışan, iş sözleşmesinin bitiminden itibaren en geç altı ay içinde yazılı olarak itiraz edebilir (SMK m. 117/3).

Çalışana ödenecek bedelin haczi bağlamında, anılan bedelin ücret olup olmadığının da tespiti gerekir. Doktrinde ücret, çalışamadığı halde ücret ödenmesini gerektiren durumların dışında, yapılan bir hizmetin karşılığı olarak, işveren veya üçüncü kişilerce işçiye sağlanan ve para veya parasal değeri bulunan menfaatlerden oluşan bir gelir çeşidi olarak tanımlanmıştır ${ }^{102}$. Anılan tanımlama çerçevesinde çalışana ödenecek bedelin ücret olmadığı kanaatindeyiz. Öte yandan çalışana (işçiye) ödenecek olan bedele ilişkin davaların Türk Borçlar Kanunu m. 146 bağlamında alacaklara ilişkin haklarına ilişkin 10 yıllık zamanaşımına tabi olması ${ }^{103} \mathrm{da}$, anılan bedelin ücret olmadığına işaret eder. Bu kapsamda çalışana ödenecek bedel üzerindeki hakkının tasarruf işlemlerine konu olabileceğini, örneğin devredilebileceğini ve dolayısıysa haczedilebileceğini söyleyebiliriz. Dolayısıyla, çalışana ödenecek bedel, ücret kapsamında değerlendirilmediğinden İIK m. 82 hükmü gereğince kısmen haczi caiz olan malvarlığı değerleri kapsamında değerlendirilmeyecek ve alacak hakkı kapsamında tamamen haczedilebilecektir.

İşveren, hizmet buluşu üzerinde kısmi hak talep ederse, hizmet buluşu serbest buluş niteliğini kazanır ve işveren, bu durumda kısmi hakka dayanmak suretiyle buluşu kullanabilir (SMK m. 115/3). Bu kapsamda ödenecek bedelin haczi konusunda bu kısımda yapmış olduğumuz açıklamalar aynen geçerlidir.

\section{b. Patent İsteme Hakkı Kapsamında Haczin Konusu}

Yukarıda ifade edildiği üzere ${ }^{104}$, ekonomik olarak değerlendirilebilen mali haklar ile buluşun alenileşmesi ya da patent alınması halinde patent üzerinde isminin belirtilmesini içeren manevi nitelikteki haklar, patent isteme hakk1 ${ }^{105}$ bütünü içinde değerlendirilir.

Patent isteme hakkının kapsamına buluşçunun buluşu ortaya çıkarması, fakat alenileştirilmemesi halinde patent başvurusuna yönelik beklenen hak, buluşçuya tanınan patent başvurusu ile patent belgesinde ve diğer ilanlarda buluşçu olarak isminin belirtilmesi hakk1 ${ }^{106}$,

\footnotetext{
102 Akın, Levent. "Maaş ve Ücret Haczi”, Ankara Üniversitesi Hukuk Fakültesi Dergisi, Y. 1995, C. 44, S. 1-4, (s.335363), s.352.

103 Canbolat, Talat. Iş̧̧̧i Buluşları, Beta Yayınları, İstanbul, 2007, s.236; Ortan, s.169

104 Bkz. yuk. I, D, 2, c.

105 Şehirali, s.56.

106 Kaya, 1997, s.174.
} 
haksız biçimde patent başvurusu yapmış kişi aleyhine dava açma hakkı ve buluş üzerinde ön kullanım hakkı tesis edilmesi hakkı girmektedir ${ }^{107}$.

Buluş sahibinin buluşunu gerçekleştirmesiyle birlikte doğan tekelci bir hakkı elde etmeye yönelik patent isteme hakkının devredilmesi mümkündür. Bu itibarla belirli bir mali değeri haiz alenileşmiş patent isteme hakkının haczedilmesi de mümkün olmalıdır ${ }^{108}$. Ancak buluş sahibinin buluşu üzerindeki isminin belirtilmesi gibi manevi nitelikteki haklarının ekonomik bir değeri bulunmadığ 1 için hacze konu edilmeleri mümkün değildir.

\section{c. Patent Başvurusundan Doğan Hak Kapsamında Haczin Konusu}

Patent başvurusundan doğan hakkın da haczi mümkündür ${ }^{109}$. Buluş sahibinin buluşuna patent verilmesi amacıyla yaptığı başvuru TÜRKPATENT nezdinde tutulan patent siciline SMK m. 106/1 uyarınca kaydedilir. Burada buluş sahibinin beklenen bir hakkının olduğu doktrinde kabul edilmektedir ${ }^{110}$.

Patent başvurusundan doğan hakkın hacze konu olabileceği ${ }^{111}$ SMK m. 148/8 ve SMKY m. 130'dan da anlaş1lmaktadır. SMK m. 148/8'de sınai mülkiyet hakkına ilişkin hükümlerin sınai mülkiyet hakkı başvurularında da uygulanacağı ifade edilmektedir. SMKY m. 130 ise SMKY m. 125-129 arasında yer alan hükümlerin, bu kapsamda haczi düzenleyen m. 126'nın, sınai mülkiyet hakkı başvuruları hakkında, dolayısıyla patent başvurusunda da uygulanacağı ve başvurunun yayımlanması halinde (m. 128 maddedeki haller hariç olmak üzere) bu hükümlerle ilgili işlemlerin/haczin de Bültende yayımlanacağına işaret edilmiştir. Yine m.130/2'de, patent başvurusunun haczinin, anılan başvurunun işlemden kalkmasına engel olmayacağı da açıkça ifade edilmiştir. Sonuç itibariyle patent başvurusundan doğan hakkın haczin konusu olacağı konusunda herhangi bir tereddüt kalmamıştır.

\section{Patentten Doğan Hak Kapsamında Haczin Konusu}

Patent başvurusunun olumlu sonuçlanması ve TÜRKPATENT tarafından patent belgesinin verilmesi ile kazanılan ve patent konusu üzerinde sahibine inhisari olarak tam bir yararlanma yetkisi veren ${ }^{112}$ patentten doğan hak, patentli buluştan yararlanma ve patent üstündeki hakların başkalarında haksız biçimde kullanılmasını önleme hakkını ihtiva eder ${ }^{113}$.

Buluşa patent verilerek hakkı tescil edilmiş kişi, patentten doğan hakkın sahibidir ve bu hak, buluşu münhasıran kullanmayı, devri kapsadığı gibi haczin de konusu olabilir ${ }^{114}$. Ayrıca SMK

\footnotetext{
107 Saraç, 2012, s.213.

108 Bolayır, s.2529; Demirci, s.63; Görgün, L. Şanal. "Eser Üzerinde Rehin Tesisi ve Cebri İcra Konusu Olarak Eser”, Ankara İktisadi ve Ticari Bilimler Dergisi, C. V, 1973/1, (s.135-168), s.164; Taş Korkmaz, 2010, s.181; Tekinalp, 2012, s.628.

109 Ayiter, s.105; Bolayır, s.2530; Hirsch, C. I, s.179; Atıc1, Cansu. Stnai Hakların Cebri Ícrası, Dokuz Eylül Üniversitesi Sosyal Bilimler Enstitüsü, Yayımlanmamış Yüksek Lisans Tezi, İzmir, 2013, s.119-120; Engelbert, s. 26-27.

110 Bolayır, s.2530; Demirci, s.56; Hirsch, C. I, s.177; Şehirali, s.56.

111 Ayiter, s.105; Bolayır, s.2530; Demirci, s.56; Ortan, s.89; Taş Korkmaz, 2010, s.182; Tekinalp, 2012, s.628.

112 Saraç, 2003, s.29.

113 Bkz. yuk. I, D, 4.

114 Bolayır, s.2530; Engelbert, s. 27-28; Koch, ZPO § 857, Rn. 21.
} 
m. 148/2 ve SMKY m. 126 uyarınca işletme ile patent hakkı ve dolayısıyla patentten doğan hak, bağımsız birer malvarlığı unsuru olarak kabul edildiğinden, patentten hakkının işletmeden bağımsız olarak haczedilmesi de mümkündür. Patent olarak tescil edilmiş patent üzerindeki hakkın işletmeden bağımsız veya işletme ile birlikte haczedilmesi ürün ve usul buluşları bağlamında mümkündür ${ }^{115}$.

$\mathrm{Bu}$ başlık altında, ek patentin, gizli patentin, buluş sahibine ait kişisel unsurları içeren patentlerin, ön kullanım hakkının haczin konusu olup olamayacağı hususları üzerinde ayrıca durulması gerektiği kanaatindeyiz.

Temel amacı patent verilmiş buluş ile bütünlük arz eden ve onun amacının gerçekleşmesi konusunda tamamlayıcı, destekleyici, ilerletici bir işlev gören ek patentlerin asıl patente bağımlı olmaları, göz önünde bulundurulması gereken en önemli unsurdur ${ }^{116}$. Bir başka ifadeyle, patent konusu buluşu mükemmelleştiren veya geliştiren ve asıl patentin konusu ile bütünlük içinde bulunan buluşların korunması için verilen ek patente (SMK m. 123/1), aksi açıkça öngörülmediği ve niteliğine aykırı düşmediği takdirde, Sınai Mülkiyet Kanunu'nun patente ilişkin hükümleri uygulanacaktır (SMK m. 123/13). Bu çerçevede ek patent, patent gibi hukuki işlemlere ve hacze konu olabilecektir. Ancak, ek patent kural olarak asıl patentin tamamlayıcısı parçası olduğundan, asıl patentlerle birlikte tasarruf işlemlerine ve hacze konu olabilecektir ${ }^{117}$. Dolayısıyla ek patent başvurusu veya ek patent, bağımsız bir patent başvurusuna ${ }^{118}$ veya bağımsız bir patente dönüşmeden (SMK m. 123/7-12) tek başına haczin konusu olamayacaktır.

Gizli patent, milli savunma menfaatleri gözetilerek verilen, belirli süre gizli tutulan bir patent siciline kaydedilen patenttir ${ }^{119}$. Başvuru tarihinden itibaren TÜRKPATENT ve Milli Savunma Bakanlığı arasındaki işbirliği çerçevesinde patent başvurusu gizlilik içinde yürütülür ${ }^{120}$. Gizlilik devam ettiği sürece patent başvurusuna ilişkin olarak TÜRKPATENT'e herhangi bir ödeme yapılmayacağı gibi (SMK m. 124/7), gizli tutulan süre için, Devletten tazminat istenebilir (SMK m. 124/6). Hakkında gizlilik kararı verilmiş bir patent başvurusu, bu kararın kaldırıldığı tarihten itibaren diğer patent başvurularıyla aynı usullere tabi olacaktır (SMK m. 124/8, c.2). Öte yandan başvuru sahibi, patent başvurusuna konu ettiği buluşunu Millî Savunma Bakanlığı'ndan alacağı izinle kısmen veya tamamen kullanabilir (SMK m. 124/5). Gizli patente ilişkin olarak tüm bu hükümler birlikte değerlendirildiğinde, milli güvenliği ilgilendiren buluşlara ilişkin patent başvurularında, gizli patente ilişkin hükümlerin uygulanıyorsa; bunların üstün kamusal menfaatin bulunması sebebiyle, gizlilik devam ettiği sürece haczedilmemesi ve bu hususa (haczedilmezliğe) ilişkin olarak açık bir kanuni düzenlemenin yapılması gerektiğ $i^{121}$; ancak, bu kapsamda Devletten

115 Hirsch, C. I, s.179; Taş Korkmaz, 2010, s.183; Tekinalp, 2012, s.628.

116 Demirci, s.100; Taş Korkmaz, 2010, s.184.

117 Taş Korkmaz, 2010, s.184; Demirci, s.100.

118 Patent başvurusunun haczin konusu olacağına ilişkin olarak bkz. yuk. II, B, 2.

119 Saraç, 2012, s.202.

120 Tekinalp, 2012, s.597-598.

121 Özellikle anılan duruma ilişkin olarak paraya çevirme işlemlerinin gerçekleştirilme durumunda [fikri ve sınai mülkiyet haklarının İIK m. 121 kapsamında paraya çevrilmesi hakkında bkz. Arkan, Sabih. Marka Hukuku, Cilt II, Ankara, Ankara Üniversitesi Hukuk Fakültesi Yayınları, 1998, s.207; Atıcı, s.71 vd.; Belek, Veysel. Markanın Devrinin, Haczinin ve Bu İşlemler Açısından Marka Değerinin İncelenmesi, Uzmanlık Tezi, Türk Patent Enstitüsü Markalar Dairesi, Ankara 2011, s.49; Çağlar, Hayrettin. Marka Hukuku Temel Hususlar, Adalet Yayınevi, Ankara, 
istenebilecek tazminatın haczedilebileceği kanaatindeyiz. Bunun haricinde, gizli patent başvurusuna konu buluşun kullanılmasına izin verilmişse veya gizlilik kararı kaldırılmışsa, artık diğer patentler gibi haczedilmesinde herhangi bir engel bulunmadığını da belirtmekte fayda görmekteyiz.

Yine, patent hakkı sahibine ait resim, isim, soyisim gibi kişisel ögeleri haiz patent hakkının haczi konusunun üzerinde durulması gerekir. Buluş sahibinin isminin patent olarak kullanılmasında anılan isim, artık şahsi alandan çıkmakta ve ekonomik bir değere sahip olduğundan, artık anılan patentin hacze konu olup olamayacağının, kişilik haklarından ayrı tutularak patent hukukuna ilişkin kural ve ilkeler 1şığında değerlendirilmesi gerekir ${ }^{122}$. Ayrıca ismini patent olarak kullanan buluş sahibinin, ismini kendi rızasıyla ticarîleştirdiği kabul edildiğinden, patent hakkının hacze konu olabileceğini söyleyebiliriz ${ }^{123}$. Nitekim, patent hakkı kullanılırken, hak sahibinin kişisel haklarına yapılacak muhtemel saldırıların TMK m. 26 hükmü uyarınca önlenmesi her zaman mümkündür ${ }^{124}$.

Patent hakkı sahibinin patent üzerindeki kullanım hakkını lisans vermek suretiyle kullandırması yahut patent hakkını devretmesi gibi hukuki işlemlerde bulunması mümkündür ${ }^{125}$. Yine bu tasarrufların yapılacağına ilişkin patent hakkı sahibinin taahhütte bulunması halinde sağlararası hukuki işlemlere konu olabilir, dolayısıyla lisans veren patent hakkı sahibinin lisans bedeli alacağı ya da devir sebebiyle almayı beklediği ücret veya bu işlemleri yapma sebebiyle verdiği taahhütten doğan alacakları haczedilebilir ${ }^{126}$.

2013, s.105; Çolak, Uğur. Türk Marka Hukuku, 2. Bask1, On İki Levha Yayıncılık, İstanbul, 2014, s.568; Demirci, s.97; Dönmez, Murat. "Marka Haczi ve Paraya Çevrilmesi”, Türkiye Barolar Birliği Dergisi, Y11 2009, Sayı 84, (s.375-385), s.383; Görgün, s.159; Kaya, Arslan. Marka Hukuku, Arıkan Yayınevi, İstanbul, 2006, s.217; Erturgut, Mine. İcra ve İflâs Hukukunda Menkullerin Paraya Çevrilmesi, Seçkin Yayınları, Ankara, 2000, s.193; Özel, Çağlar, Marka Lisans Sözleşmesi, Ankara, Seçkin Yayınları, 2002, s.41; Sivil, Osman. "Markanın Haczi ve Rehni”, Legal Fikri ve Sinai Haklar Dergisi, Yıl 2007, Sayı 9, (s.62-74), s.63; Taş Korkmaz, Hülya. "Marka Hakkının Haczi ve Paraya Çevrilmesi", İstanbul Kültür Üniversitesi Hukuk Fakültesi Dergisi, Cilt XII, Sayı 2, Y. 2013, (s.23-43), s.31-34; Tekinalp, 2012, s.466; Topuz, Gökçen. "Marka Haczi ve Paraya Çevrilmesi", Erciyes Üniversitesi Hukuk Fakültesi Dergisi, C. III, S. 2, Y1l 2008, (s.403-417), s.414; Uyar, Talih. "Paraya Çevrilmesi Özel Bir Usulü Gerektiren Mal ve Haklar İ̈K m. 121", Ankara Barosu Dergisi, Sa. 3, 1978, (s.431-435), s.431; Ülgen, Hüseyin/Teoman, Ömer/Helvac1, Mehmet/Kendigelen, Abuzer/Kaya, Arslan/Ertan, N. Füsun Nomer. Ticari Işsletme Hukuku, 3. Tıpkı Bası, Vedat Kitapçılık, İstanbul, 2009, s.410; Ünal, Mücahit. Marka Tescilinden Doğan Haklarla İlgili Hukuki Işslemler, Seçkin Yayınc1lı, Ankara, 2007, s.114-116; Ülgen, Hüseyin/Helvacı, Mehmet/Kaya, Arslan/ Nomer Ertan, Füsun. Ticari İşletme Hukuku, 6. Bası, Vedat Kitapçılık, İstanbul, 2019, s.506; Üstündağ, s.246-247; Yasaman, Hamdi/Altay, Sttkı Anlam. (Yasaman, Hamdi/Altay, Sitkı Anlam/Ayoğlu, Sttkı/Yusufoğlu, Fülürya/Yüksel, Sinan), Marka Hukuku 556 Sayll KHK Şerhi, Cilt II, Vedat Kitapçılık, İstanbul, 2004, s.713. Bu hususta geniş bilgi için ayrıca bkz. Bolayır, s.2552 vd.; Topuz, 2008, s.414-415] gizli patente ilişkin olarak gizlilik unsurunun ihlal edilmesi ve bu çerçeveden milli güvenlik açısından telafisi güç durumların ortaya çıkması muhtemeldir.

${ }^{122}$ Bu yönde markaya ilişkin açıklamalar için bkz. Bolayır, s.2525; Taş Korkmaz, 2010, s.177-178.

${ }^{123}$ Taş Korkmaz, 2010, s.185; Bolayır, s.2532; Atıc1, s.129-130.

${ }^{124}$ Kişisel hakların sahip olduğu yüksek değerler sebebiyle patent hakkının haczi sırasında TMK m. 24'ün bertaraf edilemeyeceğine ilişkin görüş için bkz. Tekinalp, 2012, s.628.

125 Atıc1, s. 130.

${ }^{126}$ Bolayır, s.2549; Demirci, s.103; Kaya, 2006, s.221; Tekinalp, 2012, s.628-629. Krş. Arkan, s.207, dn. 117. 


\section{Haczin Gerçekleştirilmesi}

\section{Genel Olarak}

Patent hakkının haczedilebileceğine açıkça cevaz veren SMK m.148/1 ve SMKY m.126/1'de, haczin nasıl gerçekleşeceğine ilişkin bir belirleme yapılmamıştır. Yine, İcra ve İflas Kanunu'nda da sınai mülkiyet haklarının hangi hükümler çerçevesinde haczedilip paraya çevrileceğine ilişkin özel bir hüküm bulunmamaktadır. Fakat Alman Medeni Usul Kanunu (ZPO) $\S 857$ Abs. 1'de taşınır, taşınmaz dışındaki diğer malvarlığı haklarının, özellikle sınai mülkiyet haklarının haczine ilişkin özel hüküm bulunmaktadır. Anılan hükme göre taşınmaz mallara ilişkin cebri icranın konusu olmayan diğer malvarlığı haklarının cebri icrası bahsi geçen hükümlere (ZPO $\S 828$ vd.) göre gerçekleştirilecektir ${ }^{127}$. Bu hüküm çerçevesinde diğer malvarlığı haklarının ve dolayısıyla patent hakkının haczinin ZPO § 828 vd. çerçevesinde gerçekleştirileceği açıkça hüküm altına alınmıştır. Türk Hukukunda ise, haciz ve paraya çevirme işlemi, özel hüküm olmasa da yine İIK hükümlerine göre yapılacaktır.

İ̈K sistematiği çerçevesinde bakıldığında kanunda haczedilebilecek mal ve hakların haczedilmeleri ve bunlara ilişkin muhafaza tedbirlerinin uygulanması bağlamında farklı hükümlerin işlerlik kazandığını söylemek gerekir. Buna göre, taşınırlara ilişkin İ̈K m. 85, alacak veya üçüncü kişilerin elinde bulunan malların ilişkin IİK m. 89, diğer hakların muhafazası için İ̈K m. 90 ve taşınmaz mallar için İİK m. 85 ve İ̈K m. 91, resmi sicile kayıtlı mallara ilişkin İ̈K m. 79/2 ve iştirak halinde tasarruf edilen mallara ilişkin olarak İİK m. 94 hükümleri uygulama alanı bulmaktadir $^{128}$.

Yargıtay, marka hakkının haczine ilişkin 2000 tarihli bir kararında ${ }^{129}$, markaların menkul veya gayrimenkul mal niteliğinde olmadıklarından taşınır veya taşınmaz mallara ilişkin İ̈K hükümlerinin uygulanamayacağına karar vermiştir. Dolayısıyla markanın eşya niteliğine haiz olmaması ve zilyetliğe de konu olamaması sebebiyle İIK'nın menkul mallara ilişkin 86. madde hükümleri, marka hakkının haczi bakımından uygulanamaz. Benzer bir şekilde, yine bir sınai mülkiyet hakkı olan patent hakkı bağlamında aynı sonuca ulaşılabilir.

$\mathrm{Bu}$ kapsamda patent hakkına ilişkin haczin ve muhafaza tedbirlerinin hangi hükümler çerçevesinde gerçekleştirileceğinin üzerinde durulması gerekmektedir. Nitekim, tescil edilmiş olan bir patentin IİK m. 79/2 bağlamında haczinin gerçekleşip gerçekleşmeyeceği üzerinde durulmasinda fayda vardir.

\section{2. İIKK m. 79/2, c. 3'ün Uygulanıp Uygulanmayacağı Sorunu}

İcra ve İflas Kanunu'nun 79. maddesinin ikinci fikrasının üçüncü cümlesine göre, resmî sicile kayıtlı malların haczi, takibin yapıldığ icra dairesince, kaydına işletilmek suretiyle doğrudan

127 Musielak/Voit/Flockenhaus, ZPO $§ 857$, Rn. 12; Lwowski, Hans-Jürgen/Hoes, Volker, Markenrechte in der Kreditpraxis, WM 1999, 771-779, s. 771, 775; Engelbert, s. 8; MüKoZPO/Smid ZPO § 857 Rn. 1 (Münchener Kommentar zur ZPO, Band 2, §§ 335-945b, (Herausgegeben von Wolfgang Krüger, Thomas Rauscher) 6. Auflage 2020 , https://beckonline.beck.de/Dokument?vpath=bibdata\%2Fkomm\%2Fmuekozpo_6_band2\%2Fzpo\%2Fcont\%2Fmuekozpo.zp o.p857.htm\&pos=1\&hlwords=on, Erişim Tarihi:08.03.2021); Koch, ZPO § 857, Rn. 19.

128 Kuru/Arslan/Yilmaz, s.239; Topuz, 2008, s.408.

129 Yargitay 11. HD, T. 09.03.2000, E. 1999/8623, K. 2000/2232 (www.kazanc1.com, Erişim Tarihi: 22.02.2021) 
da yapılabilir. Bu hüküm çerçevesinde haczin gerçekleştirilebilmesi için resmi sicile kaydı gereken bir "mal" bulunmalıdır. Dolayısıyla patent hakkının anılan hüküm kapsamında haczedilebilmesi için, öncelikli olarak kayıt yapılan sicilin resmi bir sicil olup olmadığı; sonrasında ise söz konusu hakkın hükümde yer verilen "mal" kavramı içerisinde bulunup bulunmadığının değerlendirilmesi gerekmektedir ${ }^{130}$.

Resmi bir sicil bağlamında değerlendirmede bulanabilmek için TÜRKPATENT'in idare teşkilatlanmasındaki yerinin de belirlenmesi gerekmektedir. Zira, TÜRKPATENT nezdinde tutulan sicilin resmi bir sicil olup olmadığının tespiti anılan kurumun hukuki niteliğinde yatmaktadır. Türkiye'nin teknolojik ilerlemesi başta olmak üzere, serbest rekabet ortamını oluşturmak ve araştırma geliştirme faaliyetlerinin gelişmesini sağlamak üzere Sanayi ve Teknoloji Bakanlığına bağlı, özel bütçeli Türk Patent ve Marka Kurumu kurulmuştur (Cumhurbaşkanlığ1 Kararnamesi ${ }^{131}$ m. 358). Tüzel kişiliğe sahip TÜRKPATENT, Sanayi ve Teknoloji Bakanlığı'nın vesayet denetimindedir. Bu kapsamda Türk idari teşkilatında yerinden yönetim kuruluşlarından hizmet bakımından yerinden yönetim kuruluşları arasında yer alır. $\mathrm{Bu}$ nitelendirmeler çerçevesinde TÜRKPATENT tarafindan tutulan sicilin İIK m. 79/2, c. 3 anlamında resmi sicil olduğu ortadadır. Bir başka ifadeyle, patent başvurusu ve patentin kaydedilmiş olduğu sicil (SMK m. 106) IIIK m. 79/2, c. 3 anlamında resmi sicildir. Fakat patent başvurusunun (patent başvurusundan doğan hakkın) ve patentin (patentten doğan hakkın) İIK m. 79/2, c. 3 haczi bağlamında sicilin resmi sicil olması tek başına yetmemektedir. Öte yandan sicile kaydedilen patent hakkı kapsamında yer alan hakların, anılan hükümde ifade edilen mal kavramına dahil edilmesi gerekse de, patent hakkı bakımından bunun gerçekleşmediğini ifade etmek gerekir. Yani, İIK m. 79/2, c. 3 hükmü, patent hakkının haczinde doğrudan uygulanabilir nitelikte değildir ${ }^{132}$. Zira, anılan hüküm, lafzi yorum çerçevesinde değerlendirildiğinde, maddi bir varlığı bulunmayan patent hakkının, "mal” kavramının kapsamına sokulamayacağı açıktır. Patent hakkının bu madde kapsamında haczedilebilmesi için "mal” kavramının "mal ve haklar" şeklinde değiştirilmesi gerekir"133. Bir başka ifadeyle, dönemin gereklerine uygun olması için üzerinde fazlaca düşünülmeden getirilen 3. cümlenin, resmi sicile kayıtlı mal ve hakların haczini de kapsayacak şekilde revize edilmesi gerektiğini düşünüyoruz.

Ancak resmi sicile kayıtlı patent hakkının (sicile kaydı mümkün olan patent başvurusundan doğan hak ve patentten doğan hakkın) kaydi haczinin hiç mümkün olmayacağını söylemek, İİK m. 78/1'de 7251 sayılı Kanun m. 49 ile yapılan değişiklik bağlamında mümkün değildir. Bir başka ifadeyle, patent hakkının elektronik ortamda kayden haczedilmesi, bu yeni hüküm çerçevesinde mümkün olacaktır. Hizmet bakımından yerinden yönetim kuruluşları arasında yer alan

130 Markalar açısından yer verilen tartışmalarda, markanın İIK m. 79/2 çerçevesinde haczedilebileceği yönünde bkz. Kuru, El Kitabı, s.436; Postacıoğlu/Altay, s.365; Atıc1, s.39 vd.; Taş Korkmaz, 2010, 2013, s.31-34; Yasaman/Altay, s.713-714; Topuz, 2008, s.411.

${ }^{131}$ Bakanlıklara Bağlı, İlgili, İlişkili Kurum ve Kuruluşlar ile Diğer Kurum ve Kuruluşların Teşkilatı Hakkında Cumhurbaşkanlığ Kararnamesi, 15/7/2018 tarih ve 30479 sayılı RG.

132 Aksi görüş için bkz. Bolayır, s.2549.

${ }^{133}$ Marka haczinde bu yönde bkz. Topuz, 2008, s.410. Aksi yönde bkz. Bolayır, s.2546; Atıc1, s.42. İIK'nın değiştirilmesi hususunda devam eden kanun çalışmalarında gayrimaddi mallar üzerindeki haklar ve özellikle fikri ve sınai mülkiyet haklarının cebri icrası bakımında tereddüt uyandıran ve aksaklık yaşanılan hususlar da dikkate alınmalıdır. 
TÜRKPATENT'in kendi sistemi ile Uyap sistemi arasında entegrasyonun kurulmasiyla ${ }^{134}$, patent hakkının haczi de elektronik ortamda gerçekleştirilecektir. Öte yandan haczin TÜRKPATENT nezdinde tutulan sicile kaydedilip Bültende yayımlanacağı da SMKY m. 111/1-r ve m. 126'da açıkça hüküm altına alınmıştır ${ }^{135}$. Haczin 3. kişiler bakımından etkisi ise SMKY m. 111/3 çerçevesinde ortaya koyulmuştur. Anılan hükme göre, patent başvurusu veya patentten doğan haklar, usulüne uygun bir şekilde sicile kaydedilir ve bu gerekliliğin gerçekleşmemesi halinde, iyiniyetli üçüncü kişilerin hakkı korunur. Ayrıca, haciz işleminin elektronik ortamda gerçekleştirilmesi ve sonrasında TÜRKPATENT nezdinde sicile kayıt ve ilan şartının gerçekleşmesi durumunda, borçlunun hacizden haberdar olmaması ihtimaline binaen; İIK.m.103 hükmünün işletilmesi ve ona haciz davetiyesi (103 davetiyesi) gönderilerek yokluğunda yapılan haczin bildirilmesi gerekir.

\section{3. İiK m. 94'ün Uygulanıp Uygulanamayacağı Sorunu}

Patent hakkının haczinde, İiK m. 94'ün işlerlik kazanıp kazanmayacağı hususunda bir irdeleme ve değerlendirme yapılması gerekmektedir ${ }^{136}$. İIK $\mathrm{m}$. 94'ün başlığı "iştirak halinde tasarruf edilen mallar" olmakla birlikte esasen anılan hükümde, intifa hakkı, taksim edilmemiş miras hissesi ve şirket hissesi, iştirak halinde tasarruf edilen mal hissesi ve senede bağlanmamış anonim şirketler (çıplak ve kaydi ${ }^{137}$ ) paylarının haczi (IIIK m. 94/1), borçlunun iktisap ettiği, ancak tapu veya gemi siciline kaydettirmediği mülkiyet veya diğer aynî hakların tescilini isteme hakk1 (IIK m. 94/2) ve zilyet olmak suretiyle bir taşınmaz mülkiyetinin olağanüstü zamanaşımı nedeniyle kazanılması halinde adına tescilini isteme hakkı (İiK m. 94/3) düzenlenmektedir. Bu çerçevede bakıldığında gayrimaddi mallar üzerindeki haklar, dolayısıyla sınai mülkiyet hakları ve konumuz açısından patent isteme hakkının bu madde kapsamında haczi bağlamında bir ifade metinde yer almamaktadır. Bir başka anlatımla, madde metninde "diğer malvarlı̆̆ hakları" veya "diğer haklar" tabirleri hiç kullanılmamaktadır ${ }^{138}$. Anılan hükmün gayri maddi malların, özellikle fikri ve sınai mülkiyet hukukundan doğan hakların bakımında gözden geçirilmesi ve yeniden

${ }^{134}$ Sorgulama ve haciz işlemlerinin yürütülebilmesi için kamu kurum veya kuruluşları ile Bankacılık Kanununun 3. maddesinde tanımlanan kredi kuruluşları ve finansal kuruluşlar, UYAP ile kendi sistemleri arasında entegrasyonu sağlar (İ̈K m. 78/1, c.5). Ancak güncel durumda TÜRKPATENT ile Uyap üzerinde herhangi bir entegrasyon sağlanmış değildir. Uygulamada icra müdürü, patent hakkını haczettiğine ve alınması gereken diğer muhafaza tedbirlerine (İIK m.90) ilişkin açıklamalarını içeren yazıyı (haciz müzekkeresini) elektronik tebligat (7201 sayılı Tebligat Kanunu m. 7/a/1, b.1 ve 5018 sayılı Kanun'a ekli (II) sayılı cetvel B-19) yoluyla TÜRKPATENT'e tebliğ etmektedir.

135 Anılan bu düzenlemeler olmasaydı patent hakkının sicile kaydı bağlamında, haczedilen diğer hakların muhafaza tedbirlerine ilişkin İIK m. 90 hükmüne işlerlik kazandırılabilirdi. Bu hüküm gereğince icra müdürü, haczedilen patent hakkının muhafazası için gerekli tedbir olarak, haczi derhal TÜRKPATENT'e bildirip siciline kaydettirirdi (Topuz, 2008, s.410). Bu şekilde, patent hakkı sahibinin tasarruf yetkisi kısıtlamak ve haczin iyi niyetli üçüncü kişiler bakımından hüküm doğurması için sicile kaydedilmesi gerekmektedir.

${ }^{136}$ Marka haczi açısından İ̈K m. 94'ün uygulanabileceği yönünde bkz. Aslan, Burcu. Marka Üzerindeki Hukuki İşlemler, Yayımlanmamış Yüksek Lisans Tezi, İstanbul Bilgi Üniversitesi Sosyal Bilimler Enstitüsü, İstanbul, 2007, s.70; Belek, s.50-55; Çağlar, s.105; Çolak, s.568; Demirci, s.98; Kaya, 2006, s.217; Taş Korkmaz, 2010, 2013, s.33; Tekinalp, 2012, s.466; Ünal, s.115, 120; Yasaman/Altay, s.714.

137 Anonim şirketlerin çıplak ve kaydi paylarının haczi için bkz. Topal, s.2993 vd.

138 Topuz, 2008, s.410. 
kaleme alınması uygun olacaktır ${ }^{139}$. Dolayısıyla, lafzi yorum çerçevesinde patent hakkının haczinde İIK m. 94'ün işlerlik kazanamayacağını söyleyebiliriz. Ancak patent başvurusundan doğan hak ve patentten doğan hakların haczinde IIIK m. 78/1 işlerlik kazanırken, buluş/buluşçu hakkı ile patent isteme hakkının haczinde hangi hükümlerin işlerlik kazanacağı hususu tereddüt uyandırmaktadır. Doktrinde bir görüş bu durumda, İIK m. 94'ün kıyasen uygulanmasının mümkün olacağını ifade etmektedir ${ }^{140}$.

İ̈K m. 85/1'e göre, "borçlunun kendi yedinde veya üçüncü şahısta olan taşınır mallarıyla taşınmazlarından ve alacak ve haklarından alacaklının ana, faiz ve masraflar da dahil olmak üzere bütün alacaklarına yetecek miktar haczolunur”. Anılan hüküm dikkate alındığında borçlunun sicile kaydedilmemiş ve fakat haczi caiz olan haklarının, (hatta sicile kaydedilen haklarının) bu kapsamda haczedilebileceğini söyleyebiliriz. Zaten, anılan hakların haczi için icra dairesinin haciz tutanağı düzenlemesi yeterli olmaktadır ${ }^{141}$. Bu şekilde haczedilen haklara ilişkin olarak ayrıca İIKK m. 90 çerçevesinde icra dairesi gereken muhafaza tedbirlerini de alacaktır.

Sonuç itibariyle İIK m. 94'ün bu haliyle patent haklarının haczinde işlerlik kazanamayacağı; ancak yapılacak kanun değişikliğinde bu hususa ilişkin bir düzenlemenin yapılması gerektiği kanaatindeyiz.

\section{4. İİK m. 89'un Uygulanıp Uygulanamayacağı Sorunu}

Patent hakk1, borçlunun ekonomik değere sahip malvarlı̆̆ haklarından olmakla birlikte maddi varlığa sahip olmadığı için eşya olarak kabul edilemez ve bu nedenle de mülkiyete ve zilyetliğe konu oluşturmaz ${ }^{142}$. Bu çerçevede, patent hakkı, taşınmaz eşya, alacak hakkı veya üçüncü kişi elindeki mal olarak nitelendirilemeyecek; aksine gayrimaddi mallar üzerindeki mutlak haklar içinde değerlendirilecek türdeki haklardandır. Bu sebeple, borçlunun üçüncü kişi nezdinde olan alacak veya taşınırların haczi bakımından muhafaza tedbiri niteliğinde olan İIKK m. 89'un gayrimaddi mallar üzerindeki mutlak haklar içinde değerlendirilen patent hakkının haczi bağlamında uygulanıp uygulanamayacağı, uygulanacaksa hangi çerçevede uygulanabileceğinin üzerinde durulması gerekmektedir.

Öncelikli olarak patent hakkının haczinde, alacakların ve üçüncü kişi elindeki malların haczine ilişkin hükümler (İ̈K m. 89) doğrudan uygulanamayacaktır ${ }^{143}$. Zira patent hakkı, ne alacak hakkıdır ne de taşınır bir eşya niteliğindedir. Ancak patent hakkı dolayısıyla, hak sahibinin İ̈K m. 89 bağlamında üçüncü kişi konumunda bulunan kişilerde olan bedel alacağı veya tazminat alacağının anılan hüküm çerçevesinde haczi mümkündür ${ }^{144}$. Bu kapsamda, çalışan buluşlarında, çalışanın işverenden isteyeceği bedel (SMK m. 113/5, m. 115/6, m. 117/2); gizli patentte, patent başvuru sahibinin devletten isteyebileceği tazminat (SMK m. 124/6); yükseköğretim kurumlarında

\footnotetext{
139 Aynı yönde bkz. Topuz, 2008, s.410-411. İİK m. 94'e ilişkin değişiklik önerisi hakkında bkz. Topuz, Gökçen. Hisse Haczi ve Satışı, Yetkin Yayınları, Ankara, 2009, s.311.

140 Tekinalp, 2012, s.628; Bolayır, s.2549.

141 Bkz. yuk. II ,A.

142 Suluk, Cahit/ Nal, Temel, (Karahan, Sami/Suluk, Cahit/Saraç, Tahir/Nal, Temel), Fikri Mülkiyet Hukukunun Esasları, 3. Baskı, Seçkin, Ankara, 2013, s.4-6.

143 Aynı yönde bzk. Topuz, 2008, s.409.

144 Alman hukuku bağlamında anılan hususların haczinin ZPO $§ 829$ bağlamında gerçekleştirilmesi gerektiği yönünde bkz. Musielak/Voit/Flockenhaus, ZPO § 857 Rn. 12; Engelbert, s. 28; Koch, ZPO § 857, Rn. 23.
} 
gerçekleştirilen buluşlarda, buluştan elde edilen gelirden, kurum tarafindan, buluşu yapana verilecek olan kısım (SMK m. 121/8), İiK m. 89 çerçevesinde, üçüncü kişi nezdindeki alacak kapsamında değerlendirilip muhafaza tedbirine konu edilebilecektir.

Öte yandan, patent başvurusu veya patent hakkı sahibinin patentli buluş üzerindeki kullanım hakkını lisans vermek suretiyle kullandırması (SMK m. 127, m. 129) yahut patent hakkını devretmesi (SMK m. 148/1) gibi hukuki işlemlerde bulunması mümkündür ${ }^{145}$. Örneğin, patent sahibinin belirli bir bedel karşıllığında verdiği lisans hakkı sebebiyle lisans alandan alacağı olabilir ya da gelir elde etmek amacıyla patent başvurusundan doğan hakkını belirli bir ücret karşıllğında satması mümkündür. $\mathrm{Bu}$ tür hukuki işlemler nedeniyle, hukuki işlemin karşı tarafından olan alacağının haczinde IİK $\mathrm{m}$. 89'un uygulanmasının önünde bir engel bulunmamaktadır.

Yine, SMK m. 85 çerçevesinde, patent sahibinin, yer, teknoloji alanı, ürünlerin menşei konusunda herhangi bir ayrım yapmadan, patent hakkından yararlanacağı ifade edilmekte ve bu kapsamda belgeye konu buluşa konu ürünün imali, satışı ve ithali gibi tüm ticari haklar patent sahibine ait olacaktır ${ }^{146}$. Bu kullanım dolayısıyla üçüncü kişilerde doğacak alacak haklarının haczinde de İ̈K m. 89 hükmüne işlerlik kazandırılabilir.

\section{Patent Üzerindeki Hakkın İIK m. 82 Anlamında Haczinin Caiz Olup Olmadığı}

$\mathrm{Bu}$ başlık altında değerlendirilecek olan husus doktrinde de üzerinde durulan, patent hakkının İcra ve İflas Kanunu m. 82/2 ve 82/4 bağlamında haczinin caiz olup olmadığı meselesidir. Yani, borçlunun mesleği sürdürmek için gerekli eşyalarının haczedilmezliğine ilişkin İIK m. 82/1, b.2 ve b.4'de yer alan hükmün, patent hakkını kapsayıp kapsamadığı değerlendirilmelidir. Öncelikli olarak patent hakkının "eşya" kavramı bağlamında irdelenmesi gerekir. Zira, patent, daha önce de ifade edildiği üzere, yaratıcı insan zekasının ürünüdür ve maddi mallardan ayrı bir hukuki varlık ve ekonomik değer taşıyan, gayri maddi mallar üzerindeki mutlak haktır ${ }^{147}$. Dolayısıyla anılan hüküm bağlamında, patentin eşya kavramına dahil edilmesi ve doğrudan haczedilmez olduğunun söylenmesi, doğru bir yaklaşım biçimi teşkil etmez. Bir başka ifadeyle, İiK. m.82/1, b.2 ve b.4'de “...eşya”, “... alet ve edevat" ifadelerine kullanılarak taşınır mallardan bahsedilmiş; gayri maddi malların ve özellikle fikri ve sınai mülkiyet haklarının, dolayısıyla patent haklarının hacze konu olmaları halinde bunlara hükümde yer verilmemiştir ${ }^{148}$.

Öte yandan buluş sahibi, yalnızca patent hakkına dayalı bir faaliyet icra ediyor ve bu faaliyeti de meslek kapsamında değerlendirilebiliyorsa, patent hakkının haczedilmesi, borçlu buluş sahibinin mesleki faaliyetini yapmasına engel olabilir ${ }^{149}$. Ancak yine de anılan hakkın İ̈K m. 82/1, b.2 ve b. 4 çerçevesinde borçlunun mesleğini sürdürebilmesi için lüzumlu eşyaya nazaran farklı bir ekonomik amacı ve anlamı bulunmaktadır ${ }^{150}$.

\footnotetext{
145 Atıc1, s. 130.

146 Suluk, 2020, s.275.

147 Bkz. yuk. A, 3.

148 Bolayir, s.2526.

149 Bolayir, s.2531.

${ }^{150}$ Cornaz, Patrici. L'exécution forcée des droits de propriété intellectuelle, Lausanne 2002, s.79-80 (Bolayır, s.2531'den naklen).
} 
Doktrinde bir görüş patent hakkının haczi açısından İIK m. 82/1, b.2 ve b.4 kapsamında haczedilmezliğinin doğrudan değil, kıyas yoluyla uygulanabileceğini; somut olay bağlamında patent hakkının, sahibinin geçimi için zorunlu unsurlardan biri olarak kabul edilmesi mümkün olursa, yani borçlunun bu hak dolayısıyla asgari bir düzey gözetilerek yalnızca kendisine yetecek kadar (ekonomik olarak az miktarda) gelir elde etmesi halinde anılan hakkın haczedilemeyeceğini kabul etmektedir ${ }^{151}$.

Öncelikli olarak bir mal veya hakkın haczedilmeyeceği, ancak bir kanun hükmü ile kabul edilebilir; tüzük veya yönetmelikle kabul edilemez ${ }^{152}$. Haczedilmezliğe ilişkin hükümler, özellikle İIK m. 82'de yer alan hükümlerin birçoğu, borçlunun ve ailesinin yoksul kılınıp Devletin sosyal yardımına muhtaç bırakılmaması ve borçlunun ekonomik varlığının devam ettirebilmesi düşüncelerine dayanarak düzenleme altına alınmıştır ${ }^{153}$. Söz konusu düzenlemeler niteliği itibariyle emredicidir. Dolayısıyla, anılan hükümler bağlamında lafza bağlı ve dar yorum esası geçerli olacağından, patent hakkının İ̈K m. 82/1, b.2 ve b.4 çerçevesinde doğrudan haczedilmeyeceğini söylemek doğru olmayacaktır. Fakat yukarıda yer verilen görüşün isabetle ileri sürdüğü üzere, borçlunun patent hakkının kullanımından, asgari geçim düzeyi de göz önünde tutularak, yalnızca kendisi ve ailesine yetecek ekonomik gelir elde etmesi halinde, söz konusu hakkın haczi, İİK m. 82/1, b.2 ve b.4'ün konuluş düşüncesi ile örtüşmemektedir. Zira böyle bir durumda borçlunun ekonomik olarak varlığını sürdürmesi mümkün olmazken, Devletin de ekonomik yardımına muhtaç bırakılacaktır. Borçlunun asgari geçimini sürdüremez bir duruma sokulması insani değerlere saygı ve kamu düzenine aykırılık teşkil edebilecek nitelikte sayılabilir. Bu sebeple, somut olayın koşulları çerçevesinde patent hakkının haczedilip haczedilemeyeceğinin değerlendirilmesi gerekir. Ancak, anılan sorun hakkında kesin bir çözümün ortaya koyulması için yapılacak kanun değişikliğinde, haczedilmezlik bağlamında fikri ve sınai mülkiyet haklarının ve dolayısıyla patent hakkının haczinin de göz önünde bulundurulması ve gerekli kanuni düzenlemenin yapılması isabetli olacaktır.

\section{Haczin Etkisi}

Patent hakkının geçerli bir şekilde haczedilmesi ve haciz işlemlerinin tamamlanması ile haczin etkileri ortaya çıkmaktadır.

Patent başvurusundan doğan hak ve patentten doğan hakkın haczedilmesi halinde haciz, TÜRKPATENT nezdinde tutulan sicile kaydedilir ${ }^{154}$, bültende yayımlanır (SMKY m. 126/1, m. 130/1). Patent başvurusu veya patentten doğan hakkın üçüncü şahıslara karşı da hüküm ifade edebilmesi, bu hakların sicile kaydedilmiş olmalarına bağlıdır (SMKY m. 111/3). Bir başka ifadeyle, haczin sicilde kaydedilmesi ve bültende yayınlanması ile artık üçüncü kişilerin iyiniyet iddiaları dinlenmeyecektir. Dolayısıyla sicil alenidir (SMK m. 106/1) ve haciz iyiniyetli 3. kişilere

${ }^{151}$ Bolayır, s.2531; Ayiter, s.105; Demirci, s.103.

${ }^{152}$ Kuru, El Kitab1, s.521.

153 Kuru, El Kitabı, s.503. Devlet malları ve bu nitelikteki malların haczedilmezliğinin kabulünde kamu yararı, bireysel yarar üstün tutulmuştur; haczedilmezlik kamu düzenine dayanmaktadır (Arslan/Yılmaz/Taşpınar Ayvaz/Hanağası, s.293; Kuru, El Kitabı, s.506; Kuru, İcra, s.247; Kuru/Arslan/Yılmaz, s.269; Atal1/Ermenek/Erdoğan, s.206; Pekcanıtez/Atalay/Sungurtekin Özkan/Özekes, s.274.

${ }^{154}$ Haczin sicile tescilinin bildirici nitelikte olduğu yönünde bkz. Suluk, 2020, s.405; Çolak, s.569; Sivil, s.62, 64; Taş Korkmaz, 2010, 2013, s.33; Ünal, s.124. 
karşı, ancak sicile kayıt tarihinden itibaren hüküm doğurur (SMK m.106/2). Haczin sicile tescili, alacaklı ve ilgili üçüncü kişilerin menfaatlerinin korunması amacıyla muhafaza tedbiri ${ }^{155}$ niteliğindedir ${ }^{156}$.

Patentten doğan hakkın haczedilmesi, hakkın sona ermesine ve devrine engel değildir (SMKY m. 126/2). Benzer şekilde patent başvurusundan doğan hakkın haczi de başvurunun işlemden kalkmasına engel olmaz (SMKY m. 130/2).

Sicile kaydı mümkün olmayan buluşçu hakkı ve patent isteme hakkının haczinde ise, icra dairesi, anılan hakların haczedildiği ve gerekli muhafaza tedbirlerinin (ïIK m. 90) alınmasına ilişkin açıklamalarını içeren bir yazıyı TÜRKPATENT'e elektronik tebliğ yoluyla (7201 sayılı Tebligat Kanunu m. 7/a/1, b.1 ve 5018 sayılı Kanun'a ekli (II) sayılı cetvel B-19) göndererek haciz isteyen alacaklının hakkını, üçüncü kişilerin hak iddialarına karşı̆ güvence altına alabilecektir.

Yine patent hakkının haczi, hak sahibinin hakkını kullanmasına engel teşkil etmeyecektir ${ }^{157}$. Patent hakkının haczi, alacaklıya, patenti kullanma hakk1 vermez ${ }^{158}$. Burada hak sahibi borçlu, marka veya patent hakkını devretmek dahil diğer hukuki işlemlere konu edebilir. Patent sahibi (borçlu) ise hacizden sonra da patent üzerindeki tasarruf yetkisini kullanmaya devam edebilecektir.

Patent hakk1 sahibi SMK m. 140 hükmü uyarınca, patentin tamamından, bir veya birden çok patent isteminden TÜRKPATENT'e yapacağı yazılı bir bildirimle vazgeçebilir. Vazgeçme, yazılı biçimde kuruma bildirilmesinden sonra, sicile kayıt tarihi ${ }^{159}$ itibariyle geçerli olacaktır (SMK m. 140/3-4). Ancak patent hakkı sahibi, sicile kaydedilmiş hakkın ve lisans sahibinin onayı olmadıkça patent hakkından vazgeçemez (SMK m. 140/5). Patent hakkının haczi nedeniyle haczi koyduran alacaklının, haciz nedeniyle sahip olduğu hak da bu kapsamda değerlendirilebilir. $\mathrm{Bu}$ nedenle, haciz işleminin sicile tescil edilmiş olması durumunda, patent hakkı sahibinin, patenti haczettiren alacaklının iznini almadan vazgeçme işlemini yapamayacağını kabul etmek gerekir.

Patent hakkını haczettiren alacaklı, hacizli hakların paraya çevrilmesini ve alacağının ödenmesini talep etme hakkına sahiptir. Bu hakkın dışında patent hakkı üzerinde tasarrufta bulunma yetkisi zaruri durumlar dışında yoktur. Haczi gerçekleştiren icra dairesi tarafından İIK m. 90 çerçevesinde muhafaza tedbirleri alınmalı; bu kapsamda örneğin patent hakkının tecavüze uğraması durumunda gerekli başvuruların alacaklı tarafindan yapılabilmesine imkân tanınmalıdır ${ }^{160}$. Bu çerçevede, alacaklı, hacizden sonra borçlunun yapmaya ehil olduğu ancak bilerek veya bilmeyerek ihmal etmesi sonucunda yapması gereken işlemleri ${ }^{161}$, patent hakkı

\footnotetext{
155 Burada keyfiyetin ihbarının haczin geçerliliğini etkilememekle birlikte, muhafaza tedbiri niteliği taşıdığı yönünde bkz.: Postacıŏlu, İlhan. İcra Hukuku Esaslarl, 4. Bası, İstanbul Üniversitesi Hukuk Fakültesi Yayınları, İstanbul, 1982 , s.307.

156 Demirci, s.99; Yasaman/Altay, s.712-714.

157 Danıştay, 1997 tarihli bir kararında alacaklının muvafakati olmadan borçlunun hacizli marka hakkını devredemeyeceğini hükmetmiştir. Bkz. Danıştay 19. Daire, T. 28.01.1997, 8828/24.

158 Tekinalp, 2012, s.467; Ünal, s.127.

159 Arkan, s.174; Tekinalp, 2012, s.472; Ünal, s.130.

160 Yasaman/Altay, s.718.

161 Postacioğlu, s.309.
} 
üzerindeki hakkın devamı için önceden verilmiş taahhüt gibi işlemleri, borçlu yerine geçerek yapabilmelidir.

Patent hakkı haciz yoluyla el değiştirdikten sonra, yeni patent sahibine karşı SMK m. 138 'de yer verilen hükümsüzlük hallerinden birisine dayanılarak hükümsüzlük davası açılabilir. Fakat, patent haczinden sonra; paraya çevirme işlemiyle el değiştirmesinden önce hükümsüzlük davası; patent hakkını haczettiren alacaklıya karşı değil, bu dönemde sicilde kayıtlı hak sahibi olan kişi borçlu sıfatını taşıdığından, sicilde hak sahibi olarak görünen kişiye karşı açılmalıdır ${ }^{162}$.

Patent hakkının hükümsüzlügüne karar verilirse, bu karar geçmişe de etkili olacağından patent ya da patent başvurusuna Sınai Mülkiyet Kanunu ile sağlanan korumanın hiç doğmadığı kabul edilir (SMK m. 139/1). Hükümsüzlüğüne karar verilmeden önce uygulanmış hukuki işlemler hariç diğer hukuki işlemler geçersiz olacak; bu yüzden haczin uygulanmasından sonra verilecek hükümsüzlük kararı, uygulanmış haciz işlemini etkilemeyecektir ${ }^{163}$. Dolayısıyla hükümsüzlük kararının muhatabı, patent hakkının yeni sahibi olacaktır ${ }^{164}$.

Son olarak ifade edilmelidir ki, patent hakkı üzerinde bir rehin kurulmuşsa, kurulan rehin, patent hakkının haciz nedeniyle cebri icra yoluyla satılması halinde sona erecektir (SMKY m. 127/3-c).

\section{SONUÇ}

Patent haczinde, haczin konusunu parasal değeri bulunan ve devri mümkün olan, buluşla ilgili haklar; buluş/buluşçu hakkı, patent isteme hakkı ve patent başvurusundan doğan hak ile patentten doğan hak (patentin verilmesinden doğan hak) oluşturmaktadır.

Patente yönelik gerçekleştirilecek haciz usulü bağlamında kanunlarımızda özel bir düzenleme getirilmemiştir. $\mathrm{Bu}$ sebeple, haczin gerçekleştirilmesinde, temel kanuni düzenleme olan IIIKK açısından hangi hükümlerin işlerlik kazanacağının tespiti ve değerlendirilmesi yukarıda ilgili her bir kanun maddesi ele alınarak yapılmıştır. Bu çerçevede;

- İIK m. 79/2, c. 3 hükmü bağlamında, patent başvurusu ve patentin kaydedilmiş olduğu sicil (SMK m. 106) her ne kadar resmi sicil olsa da haczin bu hükme göre gerçekleştirilmesi için sicilin resmi sicil olması tek başına yetmemekte; ayrıca sicile kaydedilen patent hakkı kapsamında yer alan hakların, anılan hükümde ifade edilen "mal" kavramına dahil olması gerekir. Bu sebeple İIK m. 79/2, c. 3 hükmü, patent hakkının haczinde doğrudan uygulanabilir nitelikte değildir. Zira anılan hüküm, lafzi yorum çerçevesinde değerlendirildiğinde, maddi bir varlığı bulunmayan patent hakkının, "mal" kavramının kapsamına sokulamayacağı açıktır. Patent hakkının bu madde kapsamında haczedilebilmesi için "mal” kavramının "mal ve haklar" şeklinde değiştirilmesi gerekir" ${ }^{165}$. Ancak resmi sicile kayıtlı patent hakkının (sicile kaydı mümkün olan patent

162 Belek, s.64; Ünal, s.130.

163 Marka için bkz. Arkan, s.168; Çolak, s.570; Çamlıbel Taylan, Esin. Marka Hakkının Kullanımıyla Paralel Ithalatın Önlenmesi, Seçkin Yayınları, Ankara, 2001, s.248; Demirci, s.99; Ünal, s.130.

164 Belek, s.65; Ünal, s.131.

165 Marka haczinde bu yönde bkz. Topuz, 2008, s.410. Aksi yönde bkz. Bolayır, s.2546; Atıc1, s.42. İIK'nın değiştirilmesi hususunda devam eden kanun çalışmalarında gayrimaddi mallar üzerindeki haklar ve özellikle fikri ve sınai mülkiyet haklarının cebri icrası bakımında tereddüt uyandıran ve aksaklık yaşanılan hususlar da dikkate alınmalıdır. 
başvurusundan doğan hak ve patentten doğan hakkın) elektronik ortamda kaydi haczi, İiK m. 78/1'de 7251 sayılı Kanun m. 49 ile yapılan değişiklik bağlamında mümkündür. TÜRKPATENT'in kendi sistemi ile Uyap sistemi arasinda entegrasyonun kurulmasiyla, patent hakkının haczi de elektronik ortamda gerçekleştirilecektir.

- İ̈K m. 94'ün lafzi yorum çerçevesinde değerlendirilmesi neticesinde, patent hakkının haczinde anılan hükmün işlerlik kazanamayacağını söyleyebiliriz. Bu sebeple, İiK m. 94'ün gayri maddi malların, özellikle fikri ve sınai mülkiyet hukukundan doğan haklar bakımından gözden geçirilmesi ve yeniden kaleme alınması uygun olacaktır.

- Haczin gerçekleşmesi açısından icra dairesinin haciz tutanağı düzenlemesi yeterli olduğu için İIK m. 85/1 hükmünün borçlunun sicile kaydedilmemiş ve fakat haczi caiz olan haklarının, (hatta sicile kaydedilen haklarının) haczedilmesinde işlerlik kazanacağını; bu şekilde haczedilen haklara ilişkin olarak ayrıca İIK m. 90 çerçevesinde icra dairesinin gereken muhafaza tedbirlerini alabileceğini söyleyebiliriz.

- Patent hakkı, ne alacak hakkı ne de taşınır bir eşya niteliğindedir ve bu sebeple, üçüncü kişilerdeki alacakların ve üçüncü kişi elindeki malların haczine ilişkin hükümler (İIK m. 89) bu hakkın haczinde doğrudan uygulanamayacaktır. Ancak patent hakkı dolayısıyla, hak sahibinin İ̈K m. 89 bağlamında üçüncü kişi konumunda bulunan kişilerde olan bedel alacağı veya tazminat alacağının anılan hüküm çerçevesinde haczi mümkündür.

- Patent hakkının haczi bağlamında İiK m. 82/1, b.2 ve b.4 hükmünün işlerlik kazanıp kazanmayacağı noktasında, anılan hükmün doğrudan uygulanacağını söylemek mümkün değildir. Ancak, borçlunun patent hakkının kullanımından, asgari geçim düzeyi de göz önünde tutularak, yalnızca kendisi ve ailesine yetecek miktarda (az) gelir elde etmesi halinde, söz konusu hakkın haczi, IIIK m. 82/1, b.2 ve b.4'ün konuluş düşüncesi ile örtüşmemekte; zira böyle bir durumda borçlunun ekonomik olarak varlığını sürdürmesi mümkün olmazken, Devletin de ekonomik yardımına muhtaç bırakılacaktır. Borçlunun asgari geçimini sürdüremez bir duruma sokulması insani değerlere saygı ve kamu düzenine aykırılık teşkil edebilecek nitelikte sayılabilir. Dolayısıyla somut olayın koşulları çerçevesinde patent hakkının haczedilip haczedilemeyeceğinin değerlendirilmesi gerekir. Ancak, anılan sorun hakkında kesin bir çözümün ortaya koyulması için yapılacak kanun değişikliğinde, haczedilmezlik bağlamında fikri ve sınai mülkiyet haklarının ve dolayısıyla patent hakkının haczinin de göz önünde bulundurulması ve gerekli kanuni düzenlemenin yapılması isabetli olacaktır. 


\section{KAYNAKÇA}

Akın, Levent. "Maaş ve Ücret Haczi”, Ankara Üniversitesi Hukuk Fakültesi Dergisi, Y. 1995, C. 44, S. 1-4, s.335-363.

Ansay, S. Şakir. Hukuk İcra ve İflâs Usulleri, İstiklâl Matbaası, Ankara, 1960.

Arı, M. Haluk. Patent Lisansı Anlaşmalarında Münhasırlık ve Bölgesel Sinırlamalar, Rekabet Kurumu, Ankara 2003. 1998.

Arkan, Sabih. Marka Hukuku, Cilt II, Ankara, Ankara Üniversitesi Hukuk Fakültesi Yayınları,

Arslan, Ramazan /Yılmaz, Ejder / Taşpınar Ayvaz, Sema /Hanağası, Emel. İcra ve İflas Hukuku, 6. Bask1, Yetkin Yayınları, Ankara, 2020.

Aslan, Burcu. Marka Üzerindeki Hukuki İşlemler, Yayımlanmamış Yüksek Lisans Tezi, İstanbul Bilgi Üniversitesi Sosyal Bilimler Enstitüsü, İstanbul, 2007.

Atalı, Murat / Ermenek, İbrahim /Erdoğan, Ersin. İcra ve İflas Hukuku, 3. Bası, Yetkin Yayınları, Ankara, 2020.

Atıc1, Cansu. Sinai Hakların Cebri İcrası, Dokuz Eylül Üniversitesi Sosyal Bilimler Enstitüsü, Yayımlanmamış Yüksek Lisans Tezi, İzmir, 2013.

Ayiter, Nuşin. İhtira Hukuku, Ankara Üniversitesi Hukuk Fakültesi Yayınları, Ankara, 1968.

Belek, Veysel. Markanın Devrinin, Haczinin ve Bu İşlemler Açısından Marka Değerinin Incelenmesi, Uzmanlık Tezi, Türk Patent Enstitüsü Markalar Dairesi, Ankara, 2011.

Berkin, Necmeddin M. İcra Hukuku Dersleri, 2. Bası, Hamle Matbaası, İstanbul, 1969.

Bolayır, Nur. "Fikri Mülkiyet Haklarında Cebri İcra Sistemi", Dokuz Eylül Üniversitesi Dergisi Özel Sayl, Prof. Dr. Hakan Pekcanitez’ e Armağan, C. I, Y. 2014, İzmir, 2015, s. 2513-2570.

Canbolat, Talat. İşçi Buluşları, Beta Yayınları, İstanbul, 2007.

Cornaz, Patrici. L'exécution forcée des droits de propriété intellectuelle, Lausanne 2002, s. 79-80 (Bolayır, s. 2531'den naklen).

Çağlar, Hayrettin. Marka Hukuku Temel Hususlar, Adalet Yayınevi, Ankara, 2013.

Çamlıbel Taylan, Esin. Marka Hakkının Kullanımıyla Paralel İthalatın Önlenmesi, Seçkin Yayınları, Ankara, 2001.

Çolak, Uğur. Türk Marka Hukuku, 2. Bask1, On İki Levha Yayıncılık, İstanbul, 2014.

Demirci, Aylin. Gayrimaddi Malların Haczi ve Paraya Çevrilmesi, Yayımlanmamış Yüksek Lisans Tezi, Ankara Üniversitesi Sosyal Bilimler Enstitüsü, Ankara, 2002.

Dönmez, Murat. "Marka Haczi ve Paraya Çevrilmesi", Türkiye Barolar Birliği Dergisi, Y11 2009, Say1 84, s. 375-385.

Engelbert, Marina, Pfändung ausgewählter Immaterial-güterrechte, FHVR, Heft 64, 2007, https://www.hwr-berlin.de/fileadmin/portal/Dokumente/Fachbereiche-Institute/FB4/Forschung/FB-4Heft-2007-64.pdf, Erişim Tarihi: 08.03.2021.

Erdem, Bahadır. Patent Hakkının Korunmasına ve Patent Hakkına İlişkin Sözleşmelere Uygulanacak Hukuk, 2. Bas1, Beta Yayıncılık, İstanbul, 2002.

Erel, Şafak. Türk Fikir ve Sanat Hukuku, 3. Bası, Yetkin Yayınları, Ankara, 2009.

Erturgut, Mine. İcra ve İflâs Hukukunda Menkullerin Paraya Çevrilmesi, Ankara, 2000, s. 193; Özel, Çağlar, Marka Lisans Sözleşmesi, Ankara, Seçkin Yayınları, 2002. 
Gottwald, Peter, Zwangsvollstreckung, Kommentar zu den $\S \S 704-915$ h ZPO mit Antrags- und Klagemustern für die Rechtspraxis, 5. Auflage, 2005.

Görgün, L. Şanal. "Eser Üzerinde Rehin Tesisi ve Cebri İcra Konusu Olarak Eser”, Ankara İktisadi ve Ticari Bilimler Dergisi, C. V, 1973/1, s. 135-168.

Güneş, İlhami. "Türk Patent Hukuku Uygulamasında İşçi (Hizmet) Buluşları, Serbest Buluş Kavramı ve Karşılaştırmalı Hukuk" Ankara Barosu Fikri Mülkiyet ve Rekabet Hukuku Dergisi, Y. 2010 Sa. 2, s. 13-23.

Güneş, İlhami. Sınai Mülkiyet Kanunu Işı̆̆ında Uygulamalı Patent ve Faydalı Model hukuku, 3. Bask1, Seçkin Yayıncılık, Ankara, 2020.

Hirsch, E. Eduard. Hukuki Bakımdan Fikrî Say, Cilt I, İstanbul Üniversitesi Hukuk Fakültesi Yayınları, İstanbul, 1942. 1948.

Hirş, E. Eduard. Fikrî ve Sinaî Haklar, Ankara Üniversitesi Hukuk Fakültesi Yayınları, Ankara,

İmre, Zahit. Medeni Hukuka Giriş, Yenilenmiş ve Genişletilmiş İkinci Bası, İstanbul, 1976.

Jäger, Carl. Das Bundesgesetz betreffend Schuldbetreitbung und Konkurs, Band I, Zürich 1911; Band II, Zürich 1911.

Karslı, Abdurrahim. İcra ve İflas Hukuku, 3. Bask1, Alternatif Yayıncılık, İstanbul, 2014.

Kaya, Arslan. "Türk Hukukunda Patentten Doğan Haklar”, İstanbul Üniversitesi Hukuk Fakültesi Dergisi, 1997, C. LV, S. 4, 1997, s.173-200. (Kaya, 1997)

Kaya, Arslan. Marka Hukuku, Arıkan Yayınevi, İstanbul, 2006. (Kaya, 2006) 2003.

Keskinci, Derya. "Hizmet Buluşları", Prof. Dr. Ergun Önen'e Armağan, Alkım Yayınevi, İstanbul, 2013.

Kılıçoğlu, Ahmet M. Sinai Haklarla Karşılaştırmalı Fikri Haklar, 2. Bası, Turhan Kitabevi, Ankara,

Koch, Raphael, Kindl/Meller-Hannich, Gesamtes Recht der Zwangsvollstreckung 4. Auflage 2021, https://beckonline.beck.de/Dokument?vpath=bibdata\%2Fkomm\%2FKinMelWolKoZV_4\%2FZPO\%2Fcont\%2FKin MelWolKoZV.ZPO.p857.glII.g14.glc.glaa.htm, Erişim Tarihi: 08.03.2021.

Kuru, Baki / Arslan, Ramazan/ Yılmaz, Ejder. İcra ve Iflas Hukuku Ders Kitabı, 28. Bask1, Yetkin Yayınları, Ankara, 2014. Kitab1)

Kuru, Baki. İcra ve İlâs Hukuku El Kitabı, 2. Baskı, Adalet Yayınevi, Ankara 2013. (Kuru, El

Kuru, Baki. İstinaf Sistemine Göre Yazılmış İcra ve İflas Hukuku, Legal Yayıncılık, İstanbul, 2016. (Kuru, İcra)

Musielak, Hans-Joachim/Voit, Wolfgang. Musielak/Voit Zivilprozessordnung mit Gerichtsverfassungsgesetz, 17., neubearbeitete Auflage, München, 2020, https://beckonline.beck.de/?vpath=bibdata\%2Fkomm\%2FMusielakZPOKO_17\%2FZPO\%2Fcont\%2FMusielakZPO KO\%2EZPO\%2Ep857\%2Ehtm, (Erişim Tarihi: 08.03.2021).

Muşul, Timuçin. İcra ve Iflas Hukuku, 6. Bask1, Ankara 2013.

Münchener Kommentar zur ZPO, Band 2, §§ 335-945b, (Herausgegeben von Wolfgang Krüger,

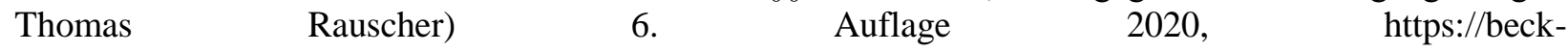
online.beck.de/Dokument?vpath=bibdata\%2Fkomm\%2Fmuekozpo_6_band2\%2Fzpo\%2Fcont\%2Fmueko zpo.zpo.p857.htm\&pos=1\&hlwords=on, (Erişim Tarihi:08.03.2021).

Noyan, Erdal. Patent Hukuku, 2. Bask1, Adalet Yayınevi, Ankara, 2011. 
Ortan, Ali Necip. İş̧̧i Buluşları Hukuku, Dokuz Eylül Üniversitesi Yayınları, İzmir, 1987.

Öztek, Selçuk. "Son Değişikliklerden Sonra Türk Patent Hukukunun Anahatları", Marmara Üniversitesi Avrupa Topluluğu Enstitüsü Avrupa Araştırmaları Dergisi, C. 4, S. 1-2, 1995-1996, s. 55-63.

Pekcanıtez, Hakan/Atalay, Oğuz/Sungurtekin Özkan, Meral/Özekes, Muhammet, İcra ve İflas Hukuku, 10. Bası, Ankara 2012. (Pekcanıtez/Atalay/Sungurtekin Özkan/Özekes)

Postacıoğlu, İlhan. İcra Hukuku Esasları, 4. Bası, İstanbul Üniversitesi Hukuk Fakültesi Yayınları, İstanbul, 1982.

Postacıoğlu, İlhan E. / Altay Sümer. İcra Hukuku Esasları, Genişletilmiş 5. Bası, Vedat Kitapçılık, İstanbul, 2010.

Saraç, Tahir. "551 Sayılı KHK'nin 11. Maddesine Göre Patent İsteme Hakk1 ve Hakkın Sahibi”, Prof. Dr. Hayri Domaniç'e 80. Yaş Günü Armağanı, Seçkin Yayınları, İstanbul, 2001. (Saraç, 2001)

Saraç, Tahir. Patentten Doğan Hakka Tecavüz ve Hakkın Korunması, Seçkin Yayıncılık, Ankara, 2003. (Saraç, 2003)

Saraç, Tahir (Karahan, Sami/Suluk, Cahit/Saraç, Tahir/Nal, Temel). Fikri Mülkiyet Hukukunun Esasları, 3. Bası, Seçkin Yayıncılık, Ankara, 2012. (Saraç, 2012)

Sarı, Onur. Patent Lisans Sözleşmeleri, Seçkin Yayınları, Ankara, 2019. https://ws1.turcademy.com/ww/webviewer.php?doc=23027, (Erişim Tarihi: 03.01.2021).

Sivil, Osman. “Markanın Haczi ve Rehni”, Legal Fikri ve Sinai Haklar Dergisi, Y11 2007, Say1 9 , s. 62-74.

Suluk, Cahit (Karasu, Rauf/Nal, Temel). Fikri Mülkiyet Hukuku, 4. Baskı, Seçkin Yayıncılık, Ankara, 2020. (Suluk, 2020)

Suluk, Cahit/ Nal, Temel, (Karahan, Sami/Suluk, Cahit/Saraç, Tahir/Nal, Temel), Fikri Mülkiyet Hukukunun Esasları, 3. Baskı, Seçkin, Ankara, 2013.

Şehirali, Feyzan H. Patent Hakkının Korunması, Turhan Kitapevi, Ankara, 1998. 2013.

Tamer, Ahmet. Patent ve Faydalı Model Hakkına Aykırılığın Sonuçları, Bilge Yayınevi, Ankara,

Taş Korkmaz, Hülya. "Marka Hakkının Haczi ve Paraya Çevrilmesi”, İstanbul Kültür Üniversitesi Hukuk Fakültesi Dergisi, Cilt XII, Sayı 2, Y. 2013, s. 23-43. (Taş Korkmaz, 2013)

Taş Korkmaz, Hülya. Iflâs Masası, Yetkin Yayınları, Ankara, 2010. (Taş Korkmaz, 2010)

Tekinalp, Ünal. “Yeni Patent Hukukunda Buluş Sahibi İlkesi”, İHFM Prof. Dr. Orhan Münir Çağıl'a Armağan Sayıs1, 1997, C.LV, S. 4, s.129-136. (Tekinalp, 1997)

Tekinalp, Ünal. Fikrî Mülkiyet Hukuku, 5. Bask1, Vedat Kitapçılık, İstanbul, 2012. (Tekinalp, 2012)

Topal, Önder. "Senede Bağlanmamış Anonim Şirket Payının Haczi”, Ankara Üniversitesi Hukuk Fakültesi Dergisi Özel Sayl: Prof. Dr. Zeki Hafizoğullarına Armağan, C. 65, S. 4, Y. 2016, (s. 2977-3016).

Topuz, Gökçen. "Marka Haczi ve Paraya Çevrilmesi”, Erciyes Üniversitesi Hukuk Fakültesi Dergisi, , C. III, S. 2, Y11 2008, s. 403-417. (Topuz, 2008)

Topuz, Gökçen. Hisse Haczi ve Satışı, Yetkin Yayınları, Ankara, 2009. (Topuz, 2009)

Uyar, Talih. "Paraya Çevrilmesi Özel Bir Usulü Gerektiren Mal ve Haklar İ̈K m. 121", Ankara Barosu Dergisi, Sa. 3, 1978, s. 431-435.

Ülgen, Hüseyin/Helvacı, Mehmet/Kaya, Arslan/ Nomer Ertan, Füsun. Ticari İşletme Hukuku, 6. Bası, Vedat Kitapçı1ı, İstanbul, 2019.

Ülgen, Hüseyin/Teoman, Ömer/Helvacı, Mehmet/Kendigelen, Abuzer/Kaya, Arslan/Ertan, N. Füsun Nomer. Ticari Işsletme Hukuku, 3. Tıpkı Bası, Vedat Kitapçılık, İstanbul, 2009. 
Ünal, Mücahit. Marka Tescilinden Doğan Haklarla İlgili Hukuki İslemler, Seçkin Yayıncılık, Ankara, 2007.

Üstündağ, Saim. İcra Hukukunun Esasları, 8. Bası, İstanbul 2004.

Yasaman, Hamdi/Altay, Sitk1 Anlam. (Yasaman, Hamdi/Altay, Sitk1 Anlam/Ayoğlu, Sitkı/Yusufoğlu, Fülürya/Yüksel, Sinan), Marka Hukuku 556 Sayılı KHK Şerhi, Cilt II, Vedat Kitapçılık, İstanbul, 2004.

Yıldırım, Kamil/ Deren-Yıldırım, Nevhis. İcra Hukuku, 5. Baskı, Beta Yayınevi, İstanbul, 2012. 